\title{
Da fotografia como arte à arte como fotografia: a experiência do Museu de Arte Contemporânea da USP na década de 1970
}

\begin{abstract}
Helouise Costa ${ }^{1}$
RESUMO: Este ensaio visa sistematizar os primeiros resultados de uma pesquisa, ainda em curso, sobre o processo de legitimação da fotografia pelo sistema de arte no Brasil, cujo foco principal é o museu. Os museus de arte da cidade de São Paulo foram escolhidos para dar início a essa investigação. Primeiramente, será abordada, em linhas gerais, a presença da fotografia no Museu de Arte Moderna de São Paulo e na Bienal de São Paulo, dada a vinculação de origem do Museu de Arte Contemporânea com essas duas instituições paulistanas. Na seqüência será analisada a formação do acervo fotográfico do Museu de Arte Contemporânea da Universidade de São Paulo durante a década de 1970. Por fim, esse percurso permitirá observar que a atuação de Walter Zanini, o primeiro diretor do Museu, e as particularidades da posição do MAC-USP no sistema de arte no Brasil naquele período resultaram no entendimento da fotografia prioritariamente no âmbito da arte contemporânea de caráter experimental e não como obra de arte autônoma, segundo os princípios da chamada fotografia artística.

PALAVRAS-CHAVE: Museu de arte. Fotografia artística. Coleção fotográfica. Museu de Arte Moderna de São Paulo. Bienal de São Paulo. Museu de Arte Contemporânea. Universidade de São Paulo.
\end{abstract}

ABSTRACT: This article presents the first findings of a research still under development about the process of legitimation of photography as a kind of art by the artistic scene in Brazil. The art museums of the city of São Paulo were chosen for starting that research. Initially, we will be investigating the presence of photography at the Contemporary Art Museum of São Paulo and at the Biennial of São Paulo, as the origin of the Contemporary Art Museum is tided to those two institutions. Following, the arrangement of the photographic technical reserve of the Contemporary Art Museum in the 1970s will be analyzed. This study will be focusing on the work of Walter Zanini, as the first director of the museum, and on the particularities of MAC-
1. Docente do Museu de Arte Contemporânea da Universidade de São Paulo. E-mail: $<$ helouise@usp.br>. 
2. Este ensaio é resultado parcial de pesquisa realizada para a Fundação de Amparo à Pesquisa do Estado de São Paulo (Fapesp) no biênio 2005-2009. Para sua elaboracão, foram consultados os arquivos do Museu de Arte Contemporânea da USP, do Museum of Modern Art New York e da Fundação Bienal de São Paulo (arquivo Wanda Svevo)

3. Fazem parte dessa rede de agentes os artistas, os marchands e galeristas, os colecionadores, os críticos, os acadêmicos, os curadores, os diretores e profissionais de museus e instituições culturais, os editores de publicações especializadas ou de divulgação, entre outros. A composição dessa rede varia de acordo com a época e os países considerados. Sobre a arte moderna e contemporânea como sistema, ver Anne Cauquelin (1992).

4. Legitimar tem sua origem etimológica ligada à palavra lei. "A legitimação é um conceito de origem políticojurídica que designa o reconhecimento, pelas instituições do poder, e segundo articulações discursivas que esse mesmo poder domina, de determinados factos sociais, sejam eles processos ou objectos. Como produto social que sempre é, a literatura esteve, desde a origem, sujeita a essa mesma legitimação". Podemos afirmar que esse fenômeno ocorre também com a arte em geral e a fotografia em particular. Ver: Dicionário eletrônico de termos literários. Acessível em: <http://www.fcsh unl.pt/edtl/verbetes/L/legitimacao.htm $>$. Acesso em dezembro de 2007.

5. Os termos coleção e acervo serão utilizados neste ensaio seguindo a sugestão de Maria Cecília França Lourenço: "Diferenciamos coleção de acervo, não tanto pelo sentido etimológico, pois praticamente coincidem no
USP position in the art system in Brazil which resulted in the understanding of photography as belonging to the sphere of contemporary art in an experimental way and not as an autonomous work of art, according to the principals of the so called artistic photography.

KEYWORDS: Art museum. Photography as art. Photographic collection. Museum of Modern Art of São Paulo. Biennial of São Paulo; Museum of Contemporary Art. University of São Paulo.

A possibilidade de integrar o projeto temático - Lugares e modos críticos da arte contemporânea nos museus - motivou-me a formalizar uma pesquisa, cujo objetivo central é resgatar o processo de legitimação da fotografia pelo sistema de arte no Brasil, tendo como foco principal o museu². Para tanto, parti do pressuposto de que o museu é uma das instâncias fundamentais do sistema de arte, e sua atuação tem profundos desdobramentos no campo da crítica e da história da arte. Por sistema de arte, entendo uma rede complexa de agentes que confere significado social à obra de arte ${ }^{3}$; e, por legitimação, o resultado de estratégias diversas, levadas a cabo por esses mesmos agentes para obter o reconhecimento, junto a seus pares, de certas modalidades de obras ou práticas artísticas, em observância a determinados sistemas de valores compartilhados ${ }^{4}$. Nessa linha interpretativa, o museu, na sua qualidade de instituição normalizadora, dita padrões de legitimação para diferentes práticas artísticas, por meio de estratégias diversas, especialmente pelas exposições que realiza, pelas publicações que organiza ou endossa, e pela política de incorporação de obras adotada para seu acervo ${ }^{5}$.

A história das instituições e de seu papel na conformação de sistemas de valores em uma determinada área de conhecimento vem, há muito tempo, sendo contemplada como objeto de investigação pela Sociologia. $\bigcirc$ mesmo não ocorre no âmbito da arte. Ao defender a autonomia da obra de arte e a subjetividade privilegiada do artista como fatores determinantes do significado da arte na sociedade moderna, a teoria estética modernista subestimou o papel das instituições na conformação dos valores artísticos. Foi somente a partir dos anos 1970, com o advento da chamada crítica pós-moderna, que o interesse pelos processos de institucionalização da arte ganhou fôlego no trabalho de autores como Rosalind Krauss, Douglas Crimp e Abigail Salomon-Goudeau, para citar apenas alguns dos nomes, cuja produção teórica refere-se mais diretamente à fotografiá. Não por acaso, parte desses autores valeu-se das questões suscitadas pela assimilação da fotografia pelo museu para fundamentar suas reflexões acerca da institucionalização da arte moderna e contemporânea e evidenciar seus paradoxos. Já no Brasil, só recentemente a institucionalização da arte moderna e contemporânea começou a ser tomada como objeto de pesquisas acadêmicas de modo mais sistemático ${ }^{7}$. Ainda assim, poucos estudos têm sido dedicados à assimilação da fotografia pelos museus nacionais ${ }^{8}$. Foi, portanto, com o intuito de atuar nesta lacuna que dei início a este projeto de pesquisa.

A primeira etapa desta investigação, realizada entre 2005 e 2007, tratou do processo de formação do acervo fotográfico do Museu de Arte Contemporânea da Universidade de São Paulo. A escolha do MAC-USP deveuse não apenas a meu vínculo profissional com a instituição, mas, principalmente, 
às peculiaridades de sua trajetória. Fundado em 1963, constituiu-se no primeiro museu de arte contemporânea do país e teve sua origem ligada ao Museu de Arte Moderna de São Paulo e à Bienal de São Paulo. Essas conexões primordiais e sua condição de museu universitário pareceram-me conferir ao MAC-USP uma trajetória complexa e particularmente propícia à realização deste estudo. Os museus universitários constituem-se em uma dupla referência no sistema de arte: além de exercerem o papel de instituição museológica, têm por princípio, como fundamento de todas as atividades que desenvolvem, a produção de conhecimento acadêmico. A vinculação universitária propicia a esse tipo de museu uma relativa autonomia em relação ao mercado de arte, o que ocorre de modo ainda mais evidente durante o período abarcado por este ensaio, quando ainda não havia um sistema de arte estruturado no país.

De início, tratarei do processo de incorporação da fotografia pelo Museu de Arte Moderna de São Paulo. Na seqüência, em linhas gerais, abordarei a presença da fotografia na Bienal, para, finalmente, analisar a experiência do Museu de Arte Contemporânea da Universidade de São Paulo na década de 1970. O recorte temporal adotado para a abordagem das instituições nacionais cobrirá os anos de 1949 a 1985, variando de acordo com as questões pertinentes a cada uma dessas instituições. As décadas seguintes deverão ser investigadas em outra oportunidade, a partir dos desdobramentos futuros da pesquisa.

A título de introdução da problemática geral desta pesquisa, cabe-nos situar o processo de legitimação da fotografia pelos museus de arte como um fenômeno complexo, engendrado por meio de três diferentes estratégias, cada uma delas com suas próprias premissas.

A primeira consistiu na institucionalização da chamada fotografia direta pelo Departamento de Fotografia do Museu de Arte Moderna de Nova York, criado em 1940. Sob a curadoria de Beaumont Newhall (1940-1945) o Departamento iria estabelecer os critérios definidores do que seria a fotografia artística $^{9}$. Segundo Cristopher Phillips a transfomação cultural que possibilitou a assimilação da fotografia como arte pelo museu foi paradoxal: o museu passou a valorizar a fotografia não enquanto imagem reprodutível e versátil, mas enquanto objeto de coleção, pautado por valores como raridade, autenticidade, expressão pessoal e virtuosismo técnico ${ }^{10}$. Essa leitura formalista da fotografia, que defende a sua pertinência ao campo da arte moderna, a sua especificidade enquanto linguagem e o seu estatuto como obra autônoma de caráter autoral, seria reiterada posteriormente por John Szarkowski, influente curador que iria dirigir o Departamento de Fotografia do museu americano entre 1962 e $1991^{11}$.

A segunda via de legitimação da fotografia pelos museus de arte deuse indiretamente, por meio da pop arte, da arte conceitual e das diferentes práticas artísticas de caráter experimental desenvolvidas ao longo das décadas de 1960 e 1970. Talvez não seja pertinente considerar que essa tenha sido uma estratégia propriamente dita, naquilo que tal tipo de ação pressupõe de planejamento, visando a objetivos claramente definidos. Os artistas que passaram intento aglutinador [...]. A palavra coleção associa-se a voluntarismos, em que um sujeito elege objetos como parte reveladora de sua existência, seja por lazer, capricho, amuleto ou vaidade [...] indica conjunto fechado e privado, transferido ou não para instituições. A escolha da palavra acervo para segmentos conectados, segundo um projeto museológico, é aqui intencional [...]. Pressupõe o debate e a eleição de critérios, o estabelecimento de plano de metas, dentro de padrões especialmente formulados segundo a realidade existente". Cf. Maria Cecília França Lourenço (1999, p. 13).

6. Tais autores estiveram vinculados ao projeto editorial da revista October nos primórdios de sua existência. Lançada em 1976, a revista teve como um dos objetivos de seu projeto editorial colocar em xeque a história da arte de cunho formalista a partir de abordagens interdisciplinares Ver Rosalind Krauss (1990); Douglas Crimp (1993); e Abigail Solomon-Goudeau (1991).

7. Ver Marcelo Mattos Araújo (2002); Maria Cecília França Lourenço (1999).

8. Ver Mariana Martins (2005); Carolina Coelho Soares (2006)

9. Beaumont Newhall foi curador do Departamento de Fotografia do MoMA de 1940 a 1945 , tendo compartilhado a gestão com sua esposa Nancy Newhall. Ver Diana Dobranszky (2008); e Beaumont Newhall (1993).

10. Ver Christopher Phillips (1982).

11. Sobre o processo de legitimação da fotografia pelo MoMA, ver também Douglas Crimp (1993). 
12. Cf. Phillipe Dubois (1994, p. 253).

13. Acerca da incorporação da fotografia às práticas artísticas contemporâneas ver Phillipe Dubois (1994); Annateresa Fabris (1996; 1998); Tony Godfrey (1998); Douglas Fogle (2003); e, ainda, Okwui Enwezor (2008).

14. Ver Marie-Laure Viale (1994).

15. Cf. Jean-François Chevrier (2003, p. 113-128) Tradução do texto, publicado originalmente em 1989, onde o autor desenvolve essa idéia. a usar a fotografia naquele momento não estavam interessados na afirmação da especificidade do medium, tampouco na discussão do estatuto artístico da fotografia. No entanto, para eles, a imagem fotográfica foi um instrumento privilegiado para colocar em xeque o estatuto tradicional da obra de arte. E foi no momento em que assimilou esses diferentes tipos de proposições artísticas que - museu acabou abrindo espaço, talvez inadvertidamente em muitos casos, a uma outra fotografia que não aquela considerada artística pelos cânones do modernismo. Phillipe Dubois afirma que, se primeiramente era a fotografia que vivia numa situação de "aspiração rumo à arte", na contemporaneidade é "a arte que insistirá em se impregnar de certas lógicas (formais, conceituais, de percepção, ideológicas ou outras) próprias à fotografia"12. A introdução da fotografia nas práticas artíticas contemporâneas, e sua conseqüente incorporação ao museu, só nos anos 1990 começou a ser melhor dimensionada, seja do ponto de vista histórico, seja a partir das implicações teóricas que levanta ${ }^{13}$.

Mais recentemente, a legitimação da fotografia pelos museus de arte assumiu uma nova estratégia. Além de serem mantidos os critérios modernistas e a incorporação dos usos híbridos herdados do período anterior, os grandes museus de arte passaram a valorizar, a partir da década de 1980, fotografias que seguem um certo modelo pictórico. Tal modelo baseia-se no uso de planos frontais bem delimitados, no estabelecimento de diálogos com a tradição da pintura desde o Renascimento, e materializa-se em fotografias em cor, de grande formato. Segundo Marie-Laure Viale, os fotógrafos Jeff Wall e Jean-Marc Bustamante reivindicaram o termo tableau (pintura/quadro) para designar suas fotografias já no final da década de 197014. Ainda de acordo com essa autora, a defesa do modelo pictórico para a fotografia contemporânea seria abraçada pela crítica a partir do final dos anos 1980, especialmente por Jean-François Chevrier, ganhando então espaço privilegiado nos museus ${ }^{15}$.

A implementação de uma dessas três estratégias de legitimação da fotografia pelos museus de arte não é necessariamente excludente em relação às demais, podendo ser concomitante até mesmo em uma única instituição, como veremos no exemplo do MAC-USP. Centraremos foco somente na primeira e na segunda dessas estratégias, dado o recorte temporal adotado para este ensaio.

A fotografia no Museu de Arte Moderna de São Paulo: do fotoclubismo ao fotojornalismo

A missão institucional de difusão e consolidação da arte moderna justificou a preocupação em inserir a fotografia como uma das modalidades artísticas contempladas pelo Museu de Arte Moderna de São Paulo logo após a sua fundação. Essa preocupação materializou-se não só na presença dos fotógrafos Thomaz Farkas, Francisco Albuquerque, Benedito Duarte e Eduardo Salvatore em comissões formadas no Museu, como também na inclusão imediata 
da fotografia na programação de exposições ${ }^{16}$. Foram ao todo nove mostras de fotografia realizadas entre 1949 e $1985^{17}$.

Tabela 1 Exposições de fotografia (MAM-SP)

\begin{tabular}{c|l|l}
\hline Ano & \multicolumn{1}{|c|}{ Mês } & \multicolumn{1}{c}{ Exposição } \\
\hline 1949 & julho & $\begin{array}{l}\text { Estudos fotográficos. } \\
\text { Thomas Farkas }\end{array}$ \\
\hline 1952 & junho & $\begin{array}{l}\text { 35 fotografias. } \\
\text { German Lorca }\end{array}$ \\
\hline 1953 & agosto-setembro & $\begin{array}{l}\text { Fernando Lemos. } \\
\text { Fotografias }\end{array}$ \\
\hline 1954 & julho & Fotografias Manarini \\
\hline 1955 & junho & $\begin{array}{l}\text { Otto Steinert e seus } \\
\text { discípulos }\end{array}$ \\
\hline 1957 & agosto & Fulvio Roiter \\
\hline 1980 & abril & $\begin{array}{l}\text { Fotografias artísticas } \\
\text { do Japão }\end{array}$ \\
\hline 1985 & junho-julho & I Trienal de Fotografia \\
\hline
\end{tabular}

As primeiras cinco exposições comprovam o papel preponderante exercido pelo Foto Cine Clube Bandeirante (FCCB) junto ao MAM-SP até meados dos anos 1950. Excetuando-se a mostra de Fernando Lemos, fotógrafo português então recém-chegado ao Brasil, as outras quatro estavam direta ou indiretamente vinculadas ao Clube, seja por se tratar de exposições de fotógrafos que pertenciam a seu quadro de associados, como o eram Thomaz Farkas, German Lorca e Ademar Manarini, seja pelo fato de a exposição ter sido intermediada pelo Bandeirante, como no caso da mostra de Otto Steinert e seus discípulos, vinda da Alemanha. Fotógrafo alemão de renome na ocasião, fundador do Grupo Fotoforma e ideólogo da chamada Fotografia Subjetiva, Otto Steinert tinha grande penetração no circuito fotoclubista internacional. Ele enviou um portfólio de cerca de cinqüenta imagens, de sua autoria e de diversos de seus alunos, para a exposição do MAM-SP18 (Figura 1).

As exposições de fotografia realizadas no MAM-SP entre os anos de 1949 e 1955 apresentam, em seu conjunto, forte coerência na legitimação
16. Eduardo Salvatore, Thomaz Farkas, Francisco Albuquerque e Benedito Duarte eram membros do Foto Cine Clube Bandeirante.

17. Este levantamento foi baseado na pesquisa de Mariana Martins (2005), realizada sob orientação da autora, para a produção de monografia final do Curso de Especialização em Museus de Arte ministrado pelo MAC-USP.

18. Após a exposição no MAM-SP, este portfolio passou a integrar o acervo do Foto Cine Clube Bandeirante. Parte dessas imagens foi apresentada na exposição FotoGrafia: a experiência alemã dos anos 50. Ver Helouise Costa (1995). 
19. Em meados dos anos 1940, Thomaz Farkas e German Lorca firmaram-se como pioneiros da fotografia moderna no Foto Cine Clube Bandeirante, juntamente com José Yalenti e Geraldo de Barros. Ademar Manarini, por sua vez, seguiu o viés experimental aberto por Geraldo de Barros na década de 1950 , concomitantemente a uma produção de caráter documental. Artista português que imigrou para o Brasil em 1953, Fernando Lemos expôs no MAM-SP uma seleção de fotos que se filiavam ora ao construtivismo, ora ao surrealismo. Ver Marcelo Mattos Araújo (2004).

20. Geraldo de Barros (1954) descreve em detalhes o processo que levou o Clube a conseguir ocupar esta sala.

21. Cf. A NOTA do Mês (1954). Quando fiz pesquisa sobre a fotografia moderna no Brasil, em 1985, não localizei documentos que comprovassem a realização dessas iniciativas. Recentemente, Mariana Martins (2005), também sem sucesso, buscou material sobrwe esses projetos.

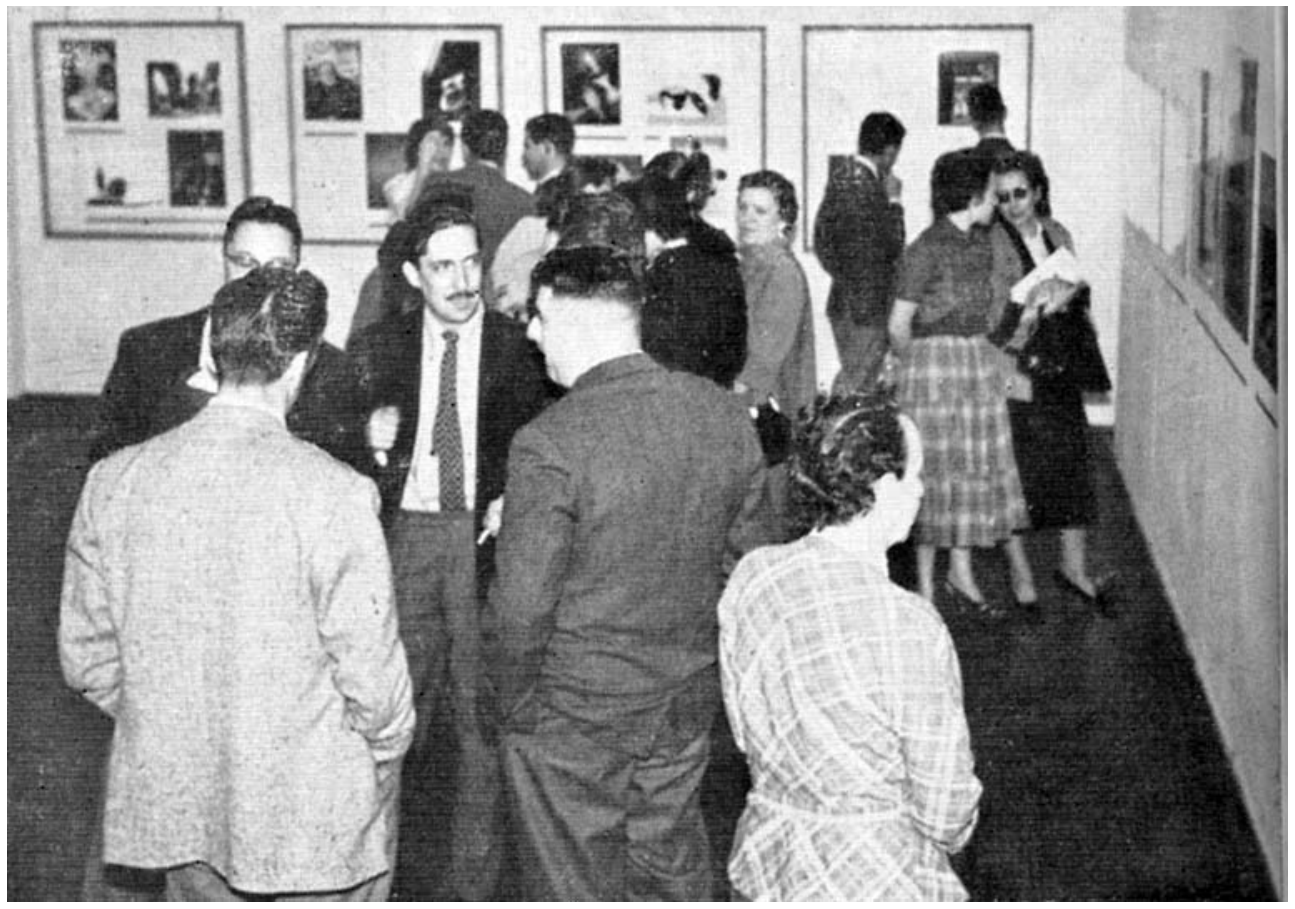

Figura 1 - Exposição Otto Steinert e seus discípulos, 1955. Museu de Arte Moderna de São Paulo. Boletim Foto Cine, São Paulo, n.97, ago-out. 1955. Arquivo Foto Cine Clube Bandeirante-SP.

artística de um certo tipo de fotografia, de herança vanguardista, que vinha sendo desenvolvida no âmbito do Foto Cine Clube Bandeirante ${ }^{19}$. A estreita relação do Bandeirante com o Museu de Arte Moderna neste período evidenciase, ainda, na realização de uma mostra de fotografia dos associados do fotoclube em uma sala especial na II Bienal de São Paulo, que, naqueles anos, ainda era um evento organizado pelo Museu de Arte Moderna ${ }^{20}$.

Um editorial do Boletim Foto Cine, datado do final de 1954, permitenos verificar que os projetos de atuação conjunta entre o Foto Cine Clube Bandeirante e o Museu de Arte Moderna de São Paulo eram bastante ambiciosos e previam realizações em curto e médio prazo.

Podemos anunciar a feliz conclusão de um convênio entre o Museu de Arte Moderna de São Paulo e o Foto Cine Clube Bandeirante para a realização - já agora em caráter oficial e em íntima colaboração entre as duas entidades - do Concurso Internacional de Fotografia Moderna, integrando a III Bienal a se realizar no próximo ano, bem como para a criação do Museu de Fotografia, realizações estas cujo alcance, significado e importância não precisamos esclarecer ${ }^{21}$.

Sabemos que nenhum desses projetos veio a concretizar-se. Após a publicação desse informe, o único evento realizado em caráter de colaboração entre as duas instituições foi a mostra de Otto Steinert, montada no MAM em 
julho de 1955. Logo depois, cessa definitivamente a participação do Bandeirante na programação do Museu. $\bigcirc$ Clube daria continuidade às mostras de seus associados e à apresentação de exposições internacionais de fotografia em sua própria sede ou na Galeria Prestes Maia 22 .

A exposição que se seguiu a de Otto Steinert no Museu de Arte Moderna foi realizada em 1957 e indica a abertura da instituição para uma nova vertente fotográfica. Fulvio Roiter, fotógrafo vinculado ao realismo italiano, apresentou fotos de tipos humanos e paisagens de cidades da Itália e da $E_{s p a n h a}^{23}$. A produção de Roiter foi apresentada primeiramente no Museu de Arte Moderna do Rio de Janeiro e, em seguida, veio a São Paulo a partir de uma proposta de itinerância. Esta foi a última exposição de fotografia realizada no MAM-SP antes da crise institucional, iniciada em 1963, em função da transferência do acervo sob sua guarda para a Universidade de São Paulo ${ }^{24}$. Ao longo das duas décadas posteriores, aconteceria somente uma única mostra: Fotografias artísticas do Japão ${ }^{25}$.

As exposições de fotografia realizadas no Museu de Arte Moderna de São Paulo ao longo de suas três primeiras décadas de existência não resultaram na incorporação de fotos ao acervo do Musev ${ }^{26}$. $\bigcirc$ ingresso da fotografia no acervo do MAM-SP iria ocorrer somente em 1980, na esteira da I Trienal de Fotografia, patrocinada pela Kodak. A exposição contou com a participação de 71 fotógrafos, e as obras contempladas com prêmios de aquisição, todas de cunho documental ou fotojornalístico, vieram a constituir o núcleo original do acervo do Museu ${ }^{27}$. Apesar de sua importância institucional, a Trienal de Fotografia não teve continuidade. Em 1985, houve uma tentativa de reeditar o evento em moldes semelhantes, por meio da I Quadrienal de Fotografia no MAM$\mathrm{SP}$, iniciativa que gerou a incorporação de mais um conjunto de fotos ao acervo, mas também não passou da primeira edição ${ }^{28}$.

Para fecharmos este percurso que trata do Museu de Arte Moderna de São Paulo, devemos notar que, ao longo das três primeiras décadas de existência do Museu, é somente até a primeira metade dos anos 50 que se observa uma agenda regular de exposições voltadas à fotografia, justamente no período em que o Foto Cine Clube Bandeirante estava próximo do Museu. No entanto, o processo de assimilação da fotografia pelo MAM-SP abrange desde o momento mais criativo do Foto Cine Clube Bandeirante, passando pela perda de prestígio do fotoclubismo, até chegar ao período de ascensão do fotojornalismo ${ }^{29}$.

$\bigcirc$ Foto Cine Clube Bandeirante desempenhou papel importante no panorama cultural da cidade de São Paulo nos anos 1950. Afinal, o fotoclubismo era o único segmento organizado entre os praticantes de fotografia, e sua contribuição residia na abordagem estética do medium. $\bigcirc$ Bandeirante foi favorecido pelo perfil da maioria de seus associados, pertencente a uma classe média próspera, que freqüentemente colocava à disposição do Clube sua rede de relações pessoais e/ou profissionais. Isso possibilitou o acesso a certos espaços culturais privilegiados, como foi o caso dos museus. $\bigcirc$ FCCB realizava
22. Ver Helouise Costa \& Renato Rodrigues da Silva (2004).

23. Cf. Mariana Martins (2005, p. 58).

24. Sobre a história institucional do Museu de Arte Moderna, ver Domingos T. Chiarelli (1998).

25. Não foram encontradas informações detalhadas desta exposição.

26. Na verdade, na ocasião, o MAM não adquiria ne nhum tipo de obra. No início, o acervo crescia por meio de doações e, posteriormente, por intermédio também dos prêmios de aquisição da Bienal de São Paulo. Como o Museu não recebeu doações de fotos e a Bienal não repassou ao $\mathrm{Mu}-$ seu nenhuma fotografia que tenha premiado, até o final dos anos 1970 não haviam sido incorporadas fotos ao acervo do MAM-SP. De qualquer modo, a questão das premiações de fotografias na Bienal de São Paulo exige um levantamento mais detido, pois, como veremos no próximo item, houve casos de fotografias premiadas como artes plásticas.

27. As fotos premiadas na I Trienal e incorporadas ao acervo são dos seguintes fotógrafos: Vera Albuquerque, Orlando Brito, Caíca, Leonardo Tiozo Hatanaka e Anna Mariani. Cf. Tadeu Chiarelli (2002, p. 9).

28. Foram incorporadas ao acervo do MAM-SP, por intermédio da I Quadrienal, fotos dos seguintes fotógrafos: Alair Gomes, Madalena Schwartz e Carlos Fadon Vicente. Segundo Tadeu Chiarelli (2002, p. 9), entre 1985 e 1995 houve a incorporação de inúmeras fotografias ao acervo do MAM-SP, de modo aleatório, tendo chegado ao fim do período com cerca de 140 fotos.

29. Uma análise detalhada da trajetória do FCCB podem ser encontrada em Helouise Costa \& Renato Rodrigues da Silva (2004). 
30. Sobre o grande contin gente de público que visitava os salões do Bandeirante cf. Helouise Costa \& Renato Rodrigues da Silva (2004, p. 122, nota 47)

31. As idéias apresentadas neste parágrafo encontram se desenvolvidas em Helouise Costa (2007).

32. A influência do FCCB permitiu, como vimos, a realização de exposições de alguns de seus associados nos museus, entre o final dos anos 1940 e meados da década seguinte, mas não resultou na musealização, na mesma ocasião, do tipo de fotografia praticado pelo Clube. Esse fenômeno só veio a ocorrer tardiamente, a partir dos anos 1990 , quando se operou um resgate histórico da importância da produção moderna fotoclubista no Brasil.

33. Em 1980, em comemoração ao centenário da Kodak, o MASP organizou um grande evento, que abarcou diversas exposições de fotografia. Cf. Carolina Coelho Soares (2006, p. 83-85).

34. Em Wolfgang Pfeiffer (1987, p. 15-18), há uma relação das premiações da Bienal de São Paulo incorporadas ao acervo do MAC-USP.

35. A primeira edição da Bienal, então chamada I Bienal do Museu de Arte Moderna de São Paulo, incluiu a Exposição Internacional de Arquitetura, além do Festival Internacional de Cinema, do Concurso de Composição Musical e do Concurso de Cerâmica. Ver MAM-SP. Catálogo Geral. São Paulo: MAM-SP, 1951. Somente na sexta edição, em 1961, o nome foi alterado para Bienal de São Paulo, quando se criou a Fundação Bienal e o evento tornou-se independente do MAM-SP. Cf. Fundação Bienal de São Paulo (2001, p. 112-113). anualmente os seus salões internacionais de fotografia na Galeria Prestes Maia, cedida ao Clube pela Prefeitura de São Paulo. Essas mostras atraíam um público amplo e diversificado, e constituíam o único evento regular dedicado à fotografia artística realizado na cidade nas décadas de 1940 e 195030. A chegada dos anos 1960, no entanto, iria modificar radicalmente tal situação.

O golpe militar de 1964 instaurou no país um regime ditatorial violento e duradouro. Naquele contexto, a posição diletante do fotoclubismo passaria a ser encarada como reacionária e inadequada em círculos culturais mais politizados ${ }^{31}$. Os fotoclubistas iriam sofrer uma sectarização crescente, especialmente por parte dos fotojornalistas, perdendo paulatinamente o espaço e a influência que haviam conquistado ${ }^{32}$. A profissão de repórter fotográfico, por sua vez, passaria a viver um período de grande reconhecimento social, pois ser-he-ia atribuída a missão de registro e denúncia das arbitrariedades do regime de exceção. Foi assim que a fotografia documental e o fotojornalismo conquistaram legitimidade para ingressarem nos museus no Brasil: afirmando-se como produção autoral e, ao mesmo tempo, colocando-se em sintonia com as demandas políticas do momento. Além disso, o fato de ter a Kodak - uma empresa multinacional da indústria fotográfica - patrocinado o ingresso da fotografia no acervo do MAM-SP parece indicar a existência de um interesse de mercado na institucionalização, entre nós, desse tipo de fotografia no início da década de $1980^{33}$.

\section{A fotografia na Bienal de São Paulo: para além da especificidade}

Cabe-nos investigar a presença da fotografia na Bienal de São Paulo em função de dois motivos principais: primeiro, pelo fato de que a maioria das obras contempladas com o prêmio aquisição pela Bienal, assim como algumas que obtiveram o prêmio regulamentar, viria a ser incorporada ao acervo do MAC-USP34; segundo, pelo importante papel de atualização em relação às tendências internacionais da arte que a Bienal exerceu durante muitas décadas em nosso meio (ver tabela na página ao lado).

A Bienal de São Paulo foi criada em 1951 pelo Museu de Arte Moderna de São Paulo e, em seu regulamento, previa a participação de obras nas categorias de pintura, escultura, desenho e gravura, que correspondiam a prêmios a serem conferidos pelo júri a artistas nacionais e estrangeiros ${ }^{35}$. A segunda edição da Bienal, no entanto, incluiu uma sala dedicada à produção fotográfica do Foto Cine Clube Bandeirante (Figuras 2 e 3). Fruto de um acordo circunstancial, uma vez que o espaço cedido ao Clube ficara vago devido à ausência de algumas representações internacionais, esse episódio dá conta do reconhecimento, por parte dos organizadores, de que a produção do Clube tinha condições de figurar em um evento do porte da Bienal de São Paulo. As fotografias foram escolhidas entre aquelas deixadas pelos associados do FCCB nos arquivos 
Exposições de fotografia ou ligadas à fotografia (Bienal de São Paulo)

\begin{tabular}{|c|c|c|}
\hline Ano & Edição & Tipo \\
\hline 1953 & II Bienal & $\begin{array}{l}\text { Sala especial de fotografia, organizada pelo Foto Cine Clube Bandeirante, com a produção de } \\
\text { seus associados }\end{array}$ \\
\hline 1965 & VIII Bienal & Seção de Fotografia organizada pelo FCCB a partir de convocação nacional \\
\hline \multirow[t]{2}{*}{1967} & IX Bienal & $\begin{array}{l}\text { Exposição Internacional de Fotografia, organizada pelo FCCB, com fotos de membros de } \\
\text { associações fotográficas nacionais e internacionais }\end{array}$ \\
\hline & & $\begin{array}{l}\text { Representação americana com a mostra Ambiente USA: } 1957 / 1967 \text { (Andy Warhol, Robert } \\
\text { Rauschenberg, Edward Ruscha etc.) } \\
\text { Waldemar Cordeiro apresenta obras produzidas a partir de fotografias }\end{array}$ \\
\hline 1969 & X Bienal & $\begin{array}{l}\text { Abolição das categorias tradicionais da arte no regulamento da Bienal (pintura, escultura, } \\
\text { desenho e gravura) } \\
\text { Supressão da Seção de Fotografia }\end{array}$ \\
\hline 1971 & XI Bienal & $\begin{array}{l}\text { Representação austríaca, com Arnulf Rainer (auto-retratos) } \\
\text { Representação da Grã-Bretanha, com Richard Long (fotos de ações) } \\
\text { Premiação de fotografias de Mario Cravo Neto }\end{array}$ \\
\hline 1973 & XII Bienal & $\begin{array}{l}\text { Grande Prêmio Latino-Americano concedido a Sérgio Augusto Porto (fotografias e espelhos; } \\
\text { projeção de slides) } \\
\text { Representação da Espanha, com Darío Villalba (objetos feitos com fotos recortadas de grandes } \\
\text { dimensões) } \\
\text { Representação da Alemanha, com Klaus Rinke (instalações com fotografias) }\end{array}$ \\
\hline 1975 & XIII Bienal & Representação da Alemanha, com Bernhard e Hilla Becher (séries fotográficas) \\
\hline 1977 & XIV Bienal & Premiação de fotografias de Hildegard Rosenthal na categoria Artes Plásticas \\
\hline
\end{tabular}

do Clube, dada a pressa com que a exposição precisou ser montada. Segundo depoimento de Geraldo de Barros, as imagens expostas receberam elogios de visitantes ilustres como Walter Gropius, Max Bill e Henri Moore ${ }^{36}$. Décadas mais tarde, Wolfgang Pfeiffer, que na época era o diretor do Museu de Arte Moderna de São Paulo, ainda se recordava da exposição com grande entusiasmo.

A mostra da Bienal foi organizada pelo Foto Cine Clube Bandeirante que reuniu, na épo$\mathrm{ca}$, grande parte dos fotógrafos importantes entre nós, pertencentes a diferentes estilos da produção fotográfica. A seleção de Manarini, Salvatore e Yalenti, feita para a Bienal [...] garantiu boa unidade, destacando o compromisso com um espírito de modernidade, escoIhendo fotografias de composições bem demarcadas e de caráter bastante "gráfico", até com a apresentação de formas absolutas, sem muito comprometimento com o público, que até então não estava habituado à leitura de obras desse tipo. Tive grande satisfação em acompanhar ativamente a organização do certame, cravado em minha memória pelo impacto visual ${ }^{37}$.
36. Geraldo de Barros (1954) descreve detalhadamente os preparativos da mostra e suas repercussões. O caráter extra-oficial da sala de fotografia do FCCB é reiterado pela ausência de registros no Arquivo Wanda Svevo, onde se encontra a documentação gerada pelas Bienais

37. Cf. Wolfgang Pfeiffer (1992, p. 3). 


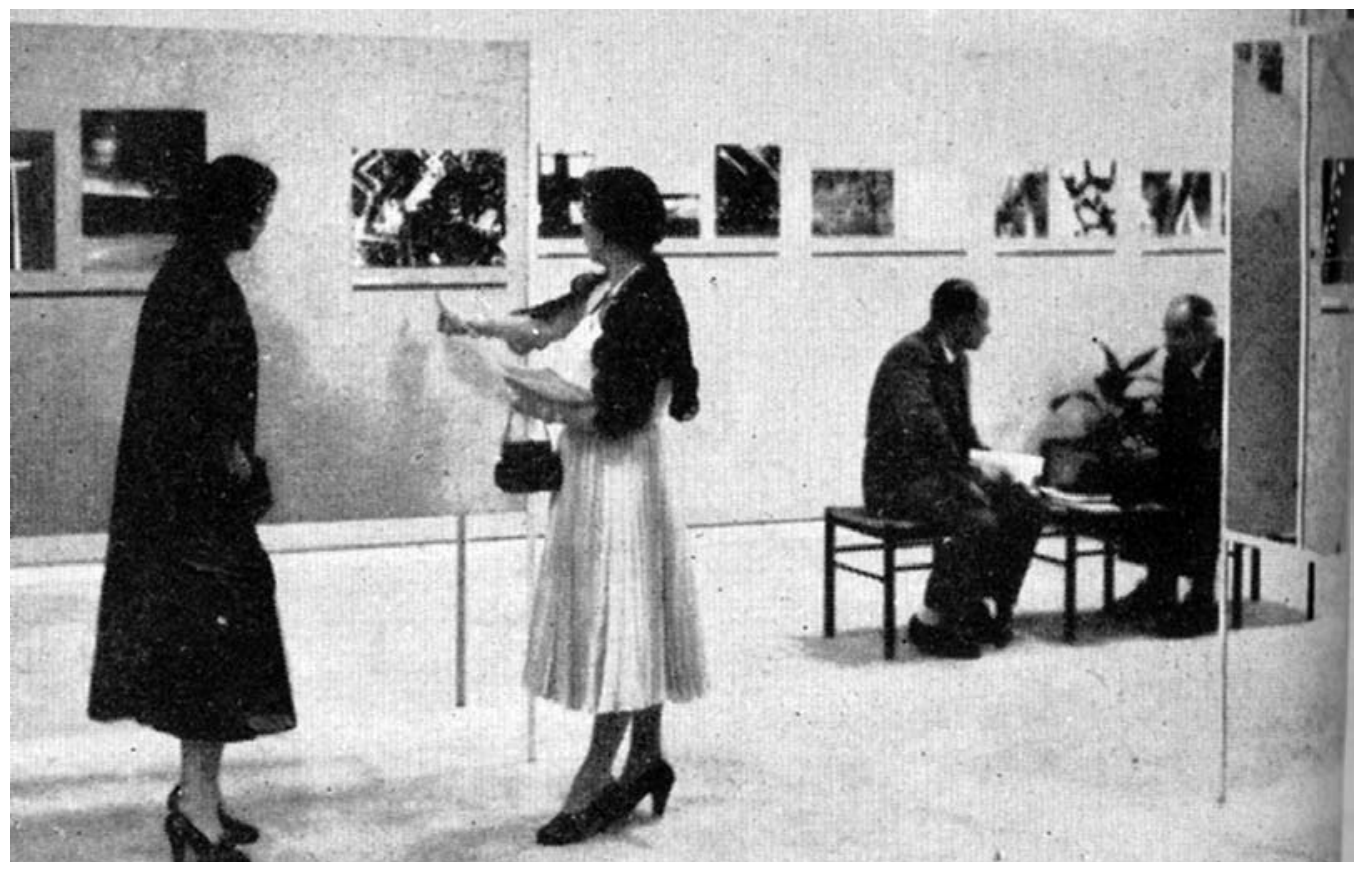

Figuras 2 - Sala Especial de Fotografia do Foto Cine Clube Bandeirante. II Bienal de São Paulo, 1953. Boletim Foto Cine, São Paulo, n.87, fev-mar. 1954, p. 12. Arquivo Foto Cine Clube Bandeirante-SP.

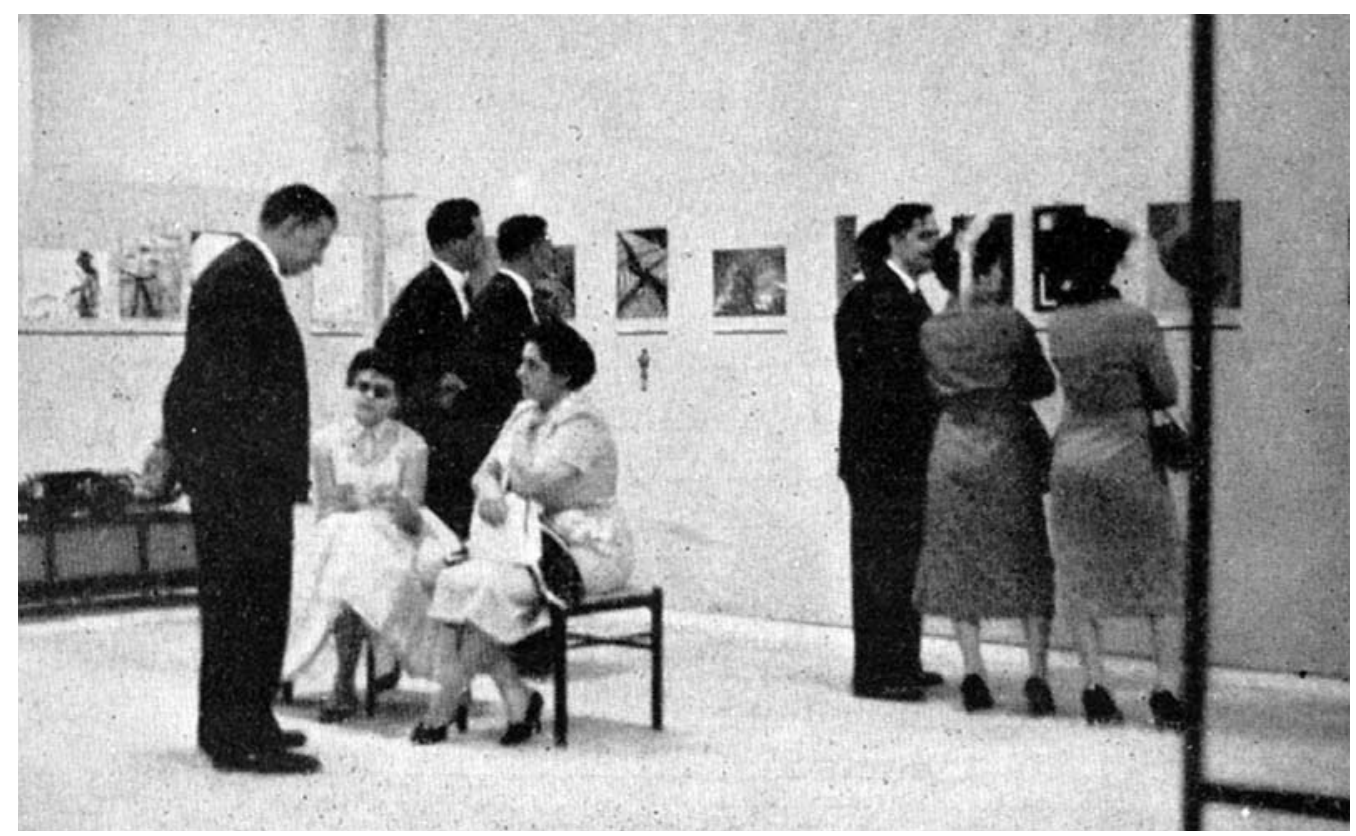

Figuras 3 - Sala Especial de Fotografia do Foto Cine Clube Bandeirante. II Bienal de São Paulo, 1953. Boletim Foto Cine, São Paulo, n.87, fev-mar. 1954, p. 12. Arquivo Foto Cine Clube Bandeirante-SP. 
A sala especial de 1953 não se colocou como um precedente determinante para a inclusão da fotografia nas Bienais que se seguiram nos anos 195038. Somente doze anos depois um artigo do Boletim Foto Cine traria a tão aguardada notícia.

Teve ampla repercussão a inclusão da fotografia artística, oficialmente, na $8^{\underline{a}}$ Bienal de São Paulo. $\bigcirc$ acontecimento foi efusivamente saudado pelos círculos fotográficos não só do país como de todo o mundo, ganhando São Paulo mais esta primazia: a de reconhecer a arte fotográfica entre as artes dignas de figurarem numa exposição tão ampla e importante como a Bienal de São Paulo ${ }^{39}$

Segundo o artigo, a decisão da Bienal de incluir a fotografia entre as modalidades artísticas por ela contempladas deu-se às vésperas da abertura da oitava mostra, em 1965, o que teria restringido a participação somente a autores nacionais, devido à exigüidade de tempo para divulgação da notícia no exterior. A mesma fonte afirma que a organização da Seção de Fotografia foi concedida ao Foto Cine Clube Bandeirante, que fez uma convocação pública para o envio de fotos. $\bigcirc$ júri foi composto por Geraldo Ferraz, crítico de arte, membro da Assessoria de Artes Plásticas da Bienal e do júri geral de seleção; Paulo Emílio Sales Gomes, diretor da Cinemateca Brasileira; e Eduardo Salvatore, presidente do FCCB.

Uma edição especial do Boletim Foto Cine foi concebida como catálogo da mostra de fotografia realizada na VIII Bienal. A publicação apresenta uma lista das 109 fotografias, selecionadas a partir de um conjunto de mais de 400 inscrições $^{40}$. Os nomes dos fotógrafos aparecem invariavelmente acompanhados das siglas das associações fotográficas a que pertencem, exceto sete, inscritos como autores independentes. Chama atenção ainda uma grande quantidade de anúncios de materiais e equipamentos fotográficos distribuídos ao longo das páginas. Um dos textos de abertura do catálogo, de responsabilidade do Bandeirante, afirma que foram selecionadas obras de "alto nível, capazes de representar condignamente a arte fotográfica brasileira contemporânea".

Em que pese a versão do Foto Cine Clube Bandeirante, expressa em seus boletins, é fundamental investigarmos melhor as condições de inclusão da fotografia na Bienal de São Paulo. Inaugurada em setembro de 1965, a VIII Bienal foi a primeira edição realizada após a instauração da ditadura militar no país. $\bigcirc$ regulamento da mostra indica que a "Exposição de Artes Plásticas" continuava sendo composta de pintura, desenho, gravura e escultura, embora o trecho relativo ao programa do evento aponte para a possibilidade de inclusão de "quaisquer outras manifestações artísticas que a Bienal resolva promover" 41 . Essa brecha parece ter aberto espaço para o convite de última hora feito ao FCCB e justificaria não haver, no Catálogo geral da VIII Bienal, qualquer menção à fotografia ou à exposição organizada pelo Clube. Note-se que mesmo o texto de Geraldo Ferraz, única manifestação oficial sobre a inclusão da fotografia na
38. Em um artigo, Jorge Radó (1960) lamenta não ter havido apresentação de fotografias artísticas na $\mathrm{V}$ Bienal de São Paulo e informa que a fotografia só foi utilizada como apoio às outras mostras.

39. Cf. A FOTOGRAFIA na $8^{\mathrm{a}}$ Bienal (1965).

40. "[...] sendo 102 na 'Secção Preto-e-Branco' e as demais na 'Secção Cor (ampliações)'. Ver BOLETIM FOTO CINE (1965). A publicação conta com um texto de abertura de Geraldo Ferraz e outro do FCCB, sem indicação de autoria. Paralelamente à VIII Bienal, o Clube organizou o XXIV Salão Internacional de Arte Fotográfica.

41. Ver Regulamento: capítulo I, artigo 2; e capítulo II, artigo 3, em BIENAL DE SÃO PAULO, 8. (1965, p. 18) 
42. BOLETIM FOTO CINE (1965).

43. Foram 257 fotógrafos de quinze países, com 527 trabalhos em preto-e-branco, cópias coloridas e diapositivos em cores. Ver BIENAL DE SÃO PAULO, 9. (1967). Infelizmente o catálogo não inclui reproduções das fotos selecionadas.

44. Fundação Bienal de São Paulo (2001, p.142).

45. O sentido dado à categoria "pesquisa" não foi encontrado no material relativo à mostra. Há, no entanto, um artigo de José Oiticica Filho (1950), em que ele se refere ao uso desse termo no ambiente fotoclubista de São Paulo, já no início dos anos 50. Ao comentar o IX Salão Internacional de São Paulo, ele afirma que valoriza as imagens que transmitem os "[...] mais altos $\mathrm{e}$ melhores sentimentos atingidos pelo homem. E tudo isso sem preconceitos contra os chamados modernistas ou 'pesquisadores' (termo que aplicado à Arte é interessante e que conheci em S. Paulo)".

46. Na VIII Bienal, dos 102 participantes da Seção Preto-e-Branco, apenas 6 não eram filiados a clubes fotográficos. Já na IX Bienal de São Paulo, participaram somente filiados à Federação Internacional de Fotografia (FIAP) e à Sociedade Fotográfica da América (PSA). Ver: BOLETIM FOTO CINE (1965) e EXPOSIÇÃO Internacional de Arte Fotográfica na IX Bienal de São Paulo. Íris, São Paulo, n. 180, 10 maio 1967.

47. X BIENAL sem fotografia. Íris, São Paulo, n. 209, 28 out. 1969, apud Mônica Junqueira Camargo \& Ricardo Mendes (1992, p. 95).

48. Regulamento, capítulo II, artigo IV, apêndice, em BIENAL DE SÃO PAULO, exposição de 1965, não faz apologia à novidade, tão valorizada pelos fotoclubistas em suas publicações ${ }^{42}$.

De qualquer modo, a expectativa do Foto Cine Clube Bandeirante em relação à IX Bienal de São Paulo acabou sendo cumprida. No Catálogo geral da mostra, consta uma seção dedicada à "Exposição Internacional de Fotografia", na qual são listados 527 trabalhos $^{43}$. $\bigcirc$ júri foi constituído por Dulce Carneiro, Geraldo de Barros e B. J. Duarte, representantes da Fundação Bienal, e por Eduardo Salvatore e Hildebrando Teixeira de Freitas, em nome do Bandeirante ${ }^{44}$. Mesmo assim, a fotografia continuava ausente do regulamento da Bienal. $\mathrm{Na}$ verdade, a exposição de fotografia parecia ser algo à parte, contando inclusive com premiações independentes, como o Troféu Bandeirante, medalhas de ouro, prata e bronze conferidas pelo FCCB, além de três prêmios, para pesquisa, oferecidos pela Kodak ${ }^{45}$.

Panorama aqui traçado aponta para uma relação no mínimo problemática da Bienal com a fotografia, ou melhor, da Bienal com uma certa fotografia, praticada e defendida pelo Foto Cine Clube Bandeirante na década de 1960. A posição do FCCB era claramente sectária, na medida em que as participações aceitas nas seções de fotografia da Bienal, sob sua responsabilidade, privilegiavam fotógrafos pertencentes a clubes e associações ${ }^{46}$. Além disso, ao que tudo indica, os critérios de seleção e premiação adotados pelo FCCB para as fotos expostas na Bienal eram os mesmos vigentes no universo do fotoclubismo. $\bigcirc$ uso de termos como "fotografia artística" ou "arte fotográfica" nos textos dos catálogos assinados pelo Clube é indicativo de uma grande defasagem em relação à produção contemporânea. Desse modo, a supressão da seção de fotografia na X Bienal não é de todo surpreendente. "Infelizmente, a próxima Bienal de São Paulo não terá mais a seção de fotografia. A direção da Bienal não ofereceu condições favoráveis para a apresentação condigna da mesma, declinando o Bandeirante do convite que the fôra feito para organizá-la. Em conseqüência, a próxima Bienal não terá a Sala de Fotografia pela qual tanto se lutou"47.

Não foi possível levantar as condições oferecidas pela Bienal, em sua edição de 1969, para a inclusão da Seção de Fotografia a que o artigo se refere. No entanto, devemos situar esse episódio em relação às mudanças gerais implementadas no evento naquele ano. A partir da décima edição o regulamento da Bienal de São Paulo foi modificado nos seguintes termos: "Para convite e inscrição, ficam abolidas as categorias de pintura, desenho, gravura, escultura e outras, considerando-se o caráter interdisciplinar da arte atual"48.

Segundo Mário Pedrosa essa mudança no regulamento teria servido apenas para referendar as inovações artísticas radicais que tomaram conta da Bienal e haviam começado a aparecer em sua sexta edição, realizada em $1961^{49}$. O crítico enfatiza a inviabilidade de conferir prêmios às obras, em função da dissolução de fronteiras entre as categorias tradicionais da arte e do caráter experimental assumido pelo processo de criação artística.

A abolição das categorias artísticas no regulamento da X Bienal de São Paulo levou a sucessivas mudanças no estabelecimento dos prêmios nas 
edições que se seguiram. É significativo que, na XI Bienal (1971), tenha sido incluída entre as premiações a categoria de Artes Visuais ao lado de Artes Plásticas, Design e Arquitetura. Na edição do evento realizada em 1973, vê-se Artes Visuais e Design ao lado de Artes Plásticas, além do surgimento da categoria Arte e Comunicação para identificar obras realizadas em audiovisual, videotape, cartão postal e performance, entre outras ${ }^{50}$. Uma análise da XIV Bienal (1977) evidencia que as categorias continuavam sendo motivo de controvérsia. As fotografias de Hildegard Rosenthal, por exemplo, foram premiadas como Artes Plásticas ${ }^{51}$. Já as obras dos artistas estrangeiros enviadas pelos diferentes países tiveram necessariamente que se encaixar em um dos sete temas estabelecidos pelo Conselho de Arte e Cultura da XIV Bienal, a saber: Arqueologia do urbano; muro como suporte de obras; Grandes confrontos; Proposições contemporâneas; A videoarte; Poesia espacial; e o inusitado Arte não catalogada ${ }^{52 .}$

A dissolução das especificidades, apontada por Mário Pedrosa, já havia possibilitado a inclusão da fotografia na Bienal por intermédio de diferentes práticas artísticas. Na IX Bienal, realizada em 1967, a representação norteamericana trouxe ao país a mostra Ambiente USA: 1957/1967, onde o público pôde ter contato com inúmeras obras que tomavam a fotografia como base de sua elaboração ${ }^{53}$. Esse foi o caso da pintura de Edward Ruscha, intitulada Posto de Gasolina da Standard, Amarillo, Texas, de 1963, realizada a partir de uma das fotos de seu primeiro livro de artista publicado em janeiro daquele ano ${ }^{54}$. Andy Warhol, por sua vez, esteve presente com três obras, produzidas a partir de fotografias apropriadas dos meios de comunicação de massas ${ }^{55}$. A estratégia de apropriação foi utilizada ainda em Búfalo II, de Robert Rauschenberg, obra premiada anteriormente na Bienal de Veneza de 1964 e exposta aqui três anos depois. Não podemos deixar de mencionar que a representação nacional da IX Bienal contou também com trabalhos que incorporavam a fotografia, como Rebolando, Auto-retrato probabilístico, Massa e/ou Indivíduo e Massa e/ou indivíduo I, todas de Waldemar Cordeiro ${ }^{56}$. Ainda foram concedidos, nessa edição, Prêmios Especiais, na categoria estrangeiros, a dois artistas poloneses - Pawel Pierscinski e Z. Lagocki - que apresentaram fotografias ${ }^{57}$.

Em que pesem as flutuações dos critérios de classificação das obras, fato é que a fotografia teve presença significativa nas edições da Bienal da segunda metade da década de 1960 e nas dos anos 197058. Devemos destacar algumas participações, além das já citadas, por sua relevância na produção contemporânea do período. Na XI Bienal, a Áustria apresentou um expressivo conjunto de 38 obras, de Arnulf Rainer, que incluía, além de desenhos, 18 fotografias, muitas dos quais continham intervenções com pastel oleoso, lápis de cor e/ou aquarela ${ }^{59}$. No mesmo ano, a Grã-Bretanha enviou ao Brasil obras de artistas que utilizavam a fotografia, a serigrafia ou a tipografia e que, em sua maioria, realizavam registros de ações. Esse foi o caso de Richard Long. Ele apresentou, na XI Bienal de São Paulo, nove fotografias que perenizavam as marcas de algumas de suas intervenções sobre terrenos desérticos ${ }^{60}$. Pedalando (1967), 21/2 Milhas de Caminhada (1968), e Traços deixados andando no
10., 1969, São Paulo. Catálogo Geral, p. 449

49. Mário Pedrosa (1995, p 273). Mário Pedrosa teve importante participação nas Bienais de São Paulo da década de 1960: foi Diretor Geral da VI e da VII Bienais (1961 e 1963) e integrou o Júri de Seleção da VI, VII e da VIII edições. Ver. Fundação Bienal de São Paulo (2001, p.168-169).

50. Fundação Bienal de São Paulo (2001, p.168-169). Levantamento realizado a partir de obras contempladas com prêmio especial na categoria Arte e Comunicação.

51. Nesta Bienal, Hildegard Rosenthal apresentou quatro fotos, sendo uma de atelier de artista e as outras três da cidade de São Paulo. Ver $<$ http://bienalsaopaulo.globo.com>.

52. Fundação Bienal de São Paulo (2001, p. 181-182).

53. Idem, p. 138-139.

54. Tratava-se do livro Twenty six gasoline stations. Ver <http://www.edruscha. com/site/chronology.cfm>. Acesso em março de 2008.

55. Obras de Andy Warhol presentes na IX Bienal: $J a$ ckie, 1964; Desastre alaranjado, 1963; e Desastre de sábado, de 1964. Ver $<$ http://bienalsaopaulo.globo.com>. Acesso em março de 2008

56. Ibidem. Sobre o uso da fotografia por Waldemar Cordeiro, ver Helouise Costa (2001). Das obras citadas, apenas Auto-retrato probabilístico sobreviveu até os dias de hoje.

57. Ver Fundação Bienal de São Paulo (2001, p. 143). Não foi possível identificar as obras premiadas.

58. Devido à variação dos critérios de classificação nas 
diversas edições da Bienal e ao uso freqüente de "técnica mista" para indicar o uso simultâneo de diferentes técnicas e/ou mídias em um mesmo trabalho, o levantamento das obras que incorporaram a fotografia requer uma pesquisa minuciosa no arquivo da Bienal e em outras fontes, o que não pôde ser realizado para este ensaio. Agradeço a Natalia Leoni, pelo suporte à pesquisa no Arquivo Wanda Svevo.

59. Ver lista de obras na pasta do artista no Arquivo Wanda Svevo. Foto do espaço expositivo pode ser encontrada em Fundação Bienal de São Paulo (2001, p. 168).

60. Ver lista de obras na pasta do artista no Arquivo Wanda Svevo.

61. Fundação Bienal de São Paulo (2001, p. 160). No site da Bienal consta que Cravo apresentou 20 fotografias de $50 \mathrm{~cm} \times 60 \mathrm{~cm}$, todas como Sem título. Não foi possível indentificá-las. O nome de Boris Kossoy também aparece na $11^{\mathrm{a}}$ edição, mas não há lista dos trabalhos expostos. Ver <http://bienalsaopaulo.globo.com $>$. Depoimento do autor, entretanto, informa de sua participação na mostra Proposições, por ocasião da XI Bienal de S.Paulo. "Naquele evento realizei exposição individual de minhas fotos e o tema apresentado reunia imagens da série Viagem pelo Fantástico. Foram expostas cerca de 10/12 fotos em $\mathrm{P} \& \mathrm{~B}$, montadas, com dimensões aproximadas de $50 \mathrm{~cm}$ $x 70 \mathrm{~cm}$. Entre as fotos expostas, recordo-me bem das seguintes: Surpresa na Estrada. Periferia de São Paulo, 1970; O Maestro. Caieiras, 1970; Noiva na Estação (1). Franco da Rocha, SP, 1970; Noiva na Estação (2). Franco da Rocha, SP, 1970; A Mulher e a Cidade. São Paulo, 1971; Aeroporto. São Paulo, 1971; Portrait na Montanha. Serra Negra, capim poeirento à margem da Estrada de África (1969) foram três dos trabalhos exibidos, resultantes das longas jornadas que empreendeu a diferentes localidades do globo a partir de meados dos anos 1960 e o tornariam conhecido como um dos precursores da land art. No que concerne às premiações, Mario Cravo Neto foi contemplado nessa edição com Prêmio Especial, na categoria artistas brasileiros, por suas fotografias ${ }^{61}$.

Nas duas Bienais seguintes, a fotografia manteria forte presença. $\mathrm{Na}$ XII Bienal, de 1973, o uso da fotografia para o registro de ações volta a ter destaque entre os estrangeiros.

A fotografia como documento de uma ação, marca característica de uma arte que se apóia no conceito em detrimento de sua própria materialidade, teria um grande momento nessa Bienal na obra do artista israelense Micha Ullmann. Troca de Terras consistia no trabalho conjunto e simultâneo de habitantes de duas aldeias, uma israelense e outra palestina, ambas com o mesmo nome e situadas uma diante da outra. Cada grupo cavou uma vala posteriormente preenhida com a terra retirada da outra vala. Com o tempo a grama cobriria a cicatriz deixada e $\mathrm{o}$ trabalho passaria a existir apenas na memória de seus participantes e testemunhas ${ }^{62}$.

O Grande Prêmio Latino-Americano, em 1973, foi concedido ao brasileiro Sérgio Augusto Porto, por uma instalação que conjugava fotografias e espelhos. Eram "fotografias em preto-e-branco de um lado e uma fileira de espelhos do outro, formando painéis em $\mathrm{L}$ em dois cantos da parede, complementados por uma projeção de slides em cor na sala ao lado"b3. Por sua vez, Darío Villalba, artista enviado pela Espanha, ocupou uma grande sala com objetos constituídos por fotos recortadas, de grandes dimensões, encapsuladas entre placas de acrílico após sofrerem intervenções à óleo ${ }^{64}$.

Na XII Bienal de São Paulo, em 1973, um espanhol, atraía especialmente a atenção, tendo ali recebido um dos prêmios maiores. Era Darío Villalba, com suas ampliações fotográficas reelaboradas, impostas sobre painéis bidimensionais ou enclausuradas em cápsulas giratórias de plástico e alumínio. A grandeza e a solenidade que emanavam daquelas imagens, exatas e violentas, incluiam-no na assumida tradição espanhola, englobando, mais remotamente, El Grego, Ribera, Velásquez e Goya e, mais próximos de nós, Canogar e vários outros 65 .

Sem dúvida, a força das imagens das obras de Villalba - apropriadas do arquivo de um hospital psiquiátrico e da imprensa diária -, bem como a solução expositiva adotada conferiram grande impacto visual aos trabalhos apresentados. Não podemos deixar de comentar, ainda, a participação na Bienal desse mesmo ano, de Klaus Rinke, pela República Federal da Alemanha. Rinke apresentou, entre outras obras, cinco instalações com fotografias, sendo algumas delas de grandes dimensões ${ }^{66}$. "Para Klauss Rinke - alemão, 34 anos, recentemente premiado na XI Bienal de São Paulo - muitas vezes é seu próprio gesto que consiste na obra de arte. E ele se limita a fotografá-lo, propondo à 
contemplação (e à reflexão) dos espectadores esse simples registro - que nem precisa ser bonito"67.

Resta-nos comentar a exposição de Bernhard e Hilla Becher, na XIII Bienal ${ }^{68}$. $\bigcirc$ casal expôs em São Paulo quatro séries, somando um total de 24 fotografias, que registravam tipologias urbanas industriais fadadas à obsolescência. Eram fotos em preto-e-branco, tomadas de um ponto de vista frontal padronizado, que transformavam caixas d'água, silos, reservatórios de gás e tantas outras estruturas, em "esculturas anônimas", como assim as denominaram os artistas. Era o primeiro contato do meio paulistano com a obra desses professores de arte que viriam a desempenhar importante papel como formadores de toda uma geração de fotógrafos contemporâneos na Alemanha, hoje conhecida como Escola de Düsseldorfo9.

Para tornar mais representativo este levantamento preliminar da presença da fotografia na Bienal de São Paulo, teria sido necessário incluir ainda uma avaliação das edições da chamada Bienal Nacional. Tratava-se de um evento relizado nos anos pares, intercalado com a Bienal Internacional de São Paulo, onde, ao que tudo indica, era dado maior espaço à fotografia de autor. Optou-se, neste estágio da pesquisa, por abordar apenas a Bienal Internacional de São Paulo, dada a dificuldade de encontrar fontes sobre o evento ${ }^{70}$.

$\bigcirc$ que se pode depreender do panorama aqui delineado é que a Bienal de São Paulo, a partir do final da década de 1960 e ao longo dos anos 1970, apresentou obras de muitos artistas representativos da cena contemporânea internacional. Embora a fotografia não tenha sido o foco das exposições, a Bienal acabou por atualizar o público local em relação ao modo como ela estava sendo introduzida no universo da arte contemporânea. Diante desse quadro, a reivindicação por um espaço específico para a fotografia na Bienal de São Paulo, reiterada insistentemente pelo Foto Cine Clube Bandeirante, desde as primeiras edições do evento, tornara-se defasada, não apenas em função da diluição de fronteiras entre as categorias artísticas tradicionais, mas também pela inclusão de novas tecnologias da imagem no campo da arte, como o vídeo e o xerox, que contribuiram para a formação de uma cultura visual mais ampla, não mais fundamentada na especificidade das linguagens, como bem apontam Camargo e Mendes $^{71}$.

A fotografia no Museu de Arte Contemporânea da Universidade de São Paulo: fotografia de autor versus fotografia experimenta|72

Museu de Arte Contemporânea foi fundado para abrigar a coleção de Francisco Matarazzo Sobrinho, transferida para a Universidade de São Paulo (USP) em 1963, que até então estava depositada no Museu de Arte Moderna de São Paulo ${ }^{73}$. Juntamente com a coleção Matarazzo, foram doados à USP não só
SP, 1971." E-mail de Boris Kossoy para a autora, 14 nov. 2008.

62. Fundação Bienal de São Paulo (2001, p.167).

63. Celina Luz. "Os espelhos da vida de Sérgio Augusto Porto". Jornal do Brasil, Rio de Janeiro, 17 out. 1973. Arquivo Wanda Svevo.

64. Parte das obras expostas na Bienal de São Paulo encontram-se reproduzidas no site do artista. Recentemente o Museu Reina Sofia, Madri, apresentou uma grande retrospectiva de seu trabalho (março a maio de 2007). Ver <http://www.dariovillalba.com/ $>$. Acesso em março de 2008 .

65. Roberto Pontual (1974) Ver também, no Arquivo Wanda Svevo, lista de obras na pasta do artista; e texto de Pierre Restany, Darío Villalba: um compromisso absoluto com o testemunho existencial, publicado no catálogo.

66. Ver <http://bienalsaopaulo.globo.com/>. Acesso em março de 2008.

67. Olívio Tavares de Araújo (1974). O artigo inclui reproduções em cores de trabalhos fotográficos do artista. Arquivo Wanda Svevo.

68. <http://bienalsaopaulo globo.com/>. Acesso em março de 2008.

69. Obras do casal Becher já haviam sido apresentadas no Brasil, na exposição Fotolinguagem, realizada no MAM-RJ, em 1973. Sobre o trabalho do casal Becher e sua influência na fotografia contemporânea alemã, ver Wulf Herzogenrath (2003)

70. A respeito do assunto, Mônica Camargo e Ricardo Mendes afirmam ser "na versão regional do evento que o espaço reservado à fotografia crescerá efetivamente. Em 1976, a Bienal Nacio- 
nal, depois substituída pela Latino-Americana, apresenta uma grande coletiva, não seletiva". Os autores informam, ainda, que a comissão organizadora dessa mostra fotográfica de 1976 foi formada por Cláudio Feijó, Eduardo Castanho, José Nogueira e Nair Benedicto. Ver Mônica Camargo e Ricardo Mendes (1992, p. 114-115). As edições do evento foram Bienal Plástica (1972), Bienal Nacional (1974 e 1976) e I Bienal Latino-Americana de São Paulo (1978).

71. Mônica Camargo e Ricardo Mendes (1992, p. 95).

72. O levantamento para a elaboração desse item devese, em grande parte, ao trabalho de Cátia Alves de Senne, bolsista de iniciação científica Pibic-CNPq (agosto 2003-julho 2006). Agradeço a Silvana Karpinski, responsável pelo Arquivo do MAC-USP, Lauci Bortoluci, responsável pela Biblioteca do MAC-USP; e a Cristina Cabral, responsável pela documentação do acervo, pelo imprescindivel suporte na pesquisa das fontes primárias. Aos estagiários Ricardo Streich e William Oliveira agradeço a digitalização dos documentos pertencentes ao MAC-USP

73. Para maiores detalhes sobre o episódio de transferência dessas coleções para a Universidade de São Paulo, ver Aracy Amaral (1988).

74. Consta que "A coleção 'Matarazzo Sobrinho/Yolanda Penteado' foi dividida juridicamente antes de ser doada para a Universidade de São Paulo, no início dos anos 60, sendo que uma parte passou a chamar-se 'Coleção Matarazzo Sobrinho' e a outra 'Coleção Matarazzo Sobrinho/Yolanda Penteado'. Esta divisão do patrimônio está ligada à separação do casal de mecenas". Cf. Ana Mae Barbosa (1990, p. 31, nota 2). Mais as obras incorporadas ao MAM-SP ao longo dos seus primeiros quinze anos de existência mas também os prêmios da Bienal de São Paulo conferidos até aquela data. No que concerne a este ensaio, interessa-nos apenas ressaltar que o núcleo que deu origem ao acervo do MAC-USP não incluía fotografias, seja pela ausência de fotos na coleção de Cicillo Matarazzo, seja em função do ingresso tardio desse medium no acervo do MAM-SP ou, ainda, pelo fato de não terem sido outorgados prêmios para a fotografia pela Bienal de São Paulo até aquela data $^{74}$

Para a direção do novo Museu, foi designado Walter Zanini, então jovem professor da Faculdade de Filosofia da USP, que iria ocupar o cargo entre 1963 e 1978. Zanini não só preenchia o principal pré-requisito para ocupar a função, que era ser docente da Universidade, como também possuía formação especializada, diferentemente da maioria dos profissionais atuantes no campo da arte no Brasil naquele período. Trazia, no currículo, um curso de graduação em História da Arte, realizado na ltália, e um estágio em Museologia no Louvre ${ }^{75}$. Por ocasião da abertura do MAC-USP, Zanini era responsável por uma disciplina optativa de história da arte no Departamento de História da Faculdade de Filosofia, Ciências e Letras da USP. Dono de um conhecimento amplo e erudito, que abarcava desde a arte clássica até o modernismo, Walter Zanini nutria ainda um forte interesse pela arte contemporânea, mantendo-se atualizado em relação às experiências inovadoras mais radicais que se realizavam no Brasil e no exterior.

Ao ser indagado sobre as questões investigadas neste ensaio, Walter Zanini afirmou que os anos 1960 foram decisivos para a fotografia, especialmente em função da pop arte, da nova figuração e do neo-dadaísmo. Como dado indicativo do reconhecimento da importância da fotografia no campo da arte na época, inclusive na área acadêmica, cita ter conhecido Aaron Sharf em Londres, no final dos anos 1950, quando o autor estava iniciando as pesquisas para o seu livro sobre as relações entre arte e fotografia, que se tornaria mais tarde importante referência sobre o tema ${ }^{77}$. Referindo-se retrospectivamente ao período de sua atuação no Museu de Arte Contemporânea, Walter Zanini lembra que naqueles tempos a fotografia exerceu um papel importante, tendo muito contribuído para o rompimento das categorias estanques da arte. "Havia uma certeza da importância da mídia fotográfica. A entrada da fotografia no Museu veio no bojo da explosão dos suportes tradicionais. De um lado estavam os fotógrafos clássicos e de outro a desmaterialização."78

De fato, essa dualidade marcou o processo de assimilação da fotografia pelo Museu de Arte Contemporânea da USP ao longo da década de 1970, como poderemos avaliar a partir do levantamento que se segue. 


\section{Tabela 3}

\section{Atividades relacionadas à fotografia (MAC-USP)}

\begin{tabular}{|c|c|c|}
\hline Ano & Data & Atividade \\
\hline 1963 & & $\begin{array}{l}\text { Beaumont Newhall e Douglas Gorsline propõe a realização de uma exposição sobre as interações entre arte e } \\
\text { fotografia (não realizada) }\end{array}$ \\
\hline 1969 & 2-27 abril & Exposição: Beleza de Pedra. Fotografias de Lenita Perroy \\
\hline \multirow[t]{3}{*}{1970} & $14-5$ a $4-6$ & Exposição: Cartier-Bresson, fotografias recentes (organizada pelo MoMA) \\
\hline & julho & Designada a Comissão de Fotografia, encarregada de estruturar o Setor de Fotografia do Museu \\
\hline & outubro & $\begin{array}{l}\text { O MAC envia uma delegação de fotógrafos como representante do estado de São Paulo a III Exposição } \\
\text { Nacional da Associação dos Museus de Arte do Brasil (AMAB), realizada no Museu de Arte Contemporânea do } \\
\text { Paraná }\end{array}$ \\
\hline \multirow[t]{4}{*}{1971} & $12-5$ a $13-6$ & Exposição: 9 Fotógrafos de São Paulo \\
\hline & & $\begin{array}{l}\text { Aquisição do primeiro conjunto de fotografias para o acervo, provenientes da exposição } 9 \text { Fotógrafos de São } \\
\text { Paulo (Maureen Bisilliat, Cristiano Mascaro e Claudia Andujar) }\end{array}$ \\
\hline & & $\begin{array}{l}\text { Participantes da exposição } 9 \text { Fotógrafos de São Paulo doam fotos ao acervo do MAC (Boris Kossoy, George } \\
\text { Love e Aldo Simoncini) }\end{array}$ \\
\hline & & Inaugurado espaço permanente para exposição de fotografias \\
\hline \multirow[t]{3}{*}{1972} & $15-6$ a $10-7$ & Inaugurada sala especial de fotografia junto à mostra Aquisições e doações recentes \\
\hline & 23-11 a 20-12 & Exposição: O fotógrafo desconhecido \\
\hline & & $\begin{array}{l}\text { Compra de um conjunto de fotografias da exposição O fotógrafo desconhecido para o acervo (Paulo Cleto, } \\
\text { Euclides Sandoval, Moema Cavalcanti, Marita Crespi, Ivan Kudrna, Antonio Carlos Antunes e Oswaldo T. } \\
\text { Oyakawa) }\end{array}$ \\
\hline 1973 & 21-31 agosto & $\begin{array}{l}\text { Exposição: Fotógrafos contemporâneos (mostra itinerante com obras do acervo da George Eastman House de } \\
\text { Rochester) } \\
\text { Cartier-Bresson doa uma fotografia ao MAC }\end{array}$ \\
\hline \multirow[t]{7}{*}{1974} & $\begin{array}{l}\text { 6-3 } 1 \text { março } \\
\text { ladiada } \\
\text { até } 15-4 \text { ) }\end{array}$ & Exposição: Fotografia experimental polonesa \\
\hline & abril & Exposição: 70 fotos de Brassaï (organizada pelo MoMA); \\
\hline & $30-5$ a $20-6$ & Exposição: Fotógrafos nacionais do acervo* \\
\hline & $31-10$ a $21-11$ & Exposição: Hildegard Rosenthal - fotografias \\
\hline & & $\begin{array}{l}\text { Consulado Geral da Polônia doa as } 38 \text { obras apresentadas na exposição Fotografia experimental polonesa } \\
\text { ao acervo do Museu }\end{array}$ \\
\hline & & Incorporação das fotografias apresentadas na exposição Hildegard Rosenthal - fotografias ao acervo do MAC \\
\hline & & Incorporação de fotografias de Alice Brill ao acervo do MAC \\
\hline \multirow[t]{2}{*}{1976} & $9-6$ a $9-8$ & Exposição: Multimedia III \\
\hline & $21-10$ a $21-11$ & Exposição: Novos e novíssimos fotógrafos \\
\hline 1977 & outubro & Exposição: Fotografias de Dario Chiaverini \\
\hline 1978 & & Fim da gestão de Walter Zanini. O MAC permanecerá fechado durante a maior parte do ano \\
\hline
\end{tabular}

* Boletim Informativo, São Paulo, n. 230, 28 maio 1974. A exposição contou com 48 obras, do acervo do MAC, dos fotógrafos George Love, Claudia Andujar, Aldo Simoncini, Boris Kossoy, Cristiano Mascaro, Paulo de Andrade, Paulo Cleto, Moema Cavalcanti, Ivan Kudrna, Marita Crespi, Euclides Sandoval e Oswaldo Oyakawa. 
informações sobre os prêmios incorporados ao acervo do MAC-USP, ver Ana Mae Barbosa (1987).

75. Informações obtidas por meio de entrevista realizada pela autora com o prof. Walter Zanini em abril de 2006.

76. Sobre a introdução do ensino de história da arte na USP, ver Walter Zanini (1994).

77. Aaron Sharf (1979). Walter Zanini redigiu diversos textos sobre fotografia nos catálogos das exposições do MAC-USP que serão analisados adiante. Sobre o tema, foi possível levantar também o texto de Walter Zanini (1954) sobre a natureza artística da fotografia. Cabe assinalar ainda, que na qualidade de organizador do livro História Geral da Arte no Brasil, Zanini convidou Boris Kossoy para escrever um capítulo sobre fotografia. A inclusão da fotografia no campo da história da arte colocou-se na época como uma contribuição inovadora em nosso meio. Ver Walter Zanini (1983).

78. Entrevista realizada pela autora com o prof. Walter Zanini em abril de 2006.

79. MAC-USP. Boletim Informativo, São Paulo, n. 2, 1963.

80. Beaumont Newhall foi nomeado curador da George Eastman House, de Rochester, em 1948 e, dez anos depois, assumiu a direção geral da instituição, onde permaneceu até 1971. Cf. Beaumont Newhall (1993, p. 190-228). Cabe acrescentar que o MAC-USP iria realizar uma exposição de sua produção fotográfica em meados de 1987 . Ver pasta 0072/005, Arquivo MAC-USP.

81. Consta em um dos boletins do MAC-USP que, para viabilizar a exposição, o Museu trocou correspondência
Poucos meses após a fundação do MAC-USP, Beaumont Newhall enviou a Walter Zanini, por intermédio do pintor Douglas Gorsline, solicitação de cooperação para a vinda ao Brasil de uma exposição sobre as interações entre fotografia e arte moderna, ainda em fase de elaboração ${ }^{79}$. Na ocasião, o ex-curador do Departamento de Fotografia do MoMA atuava como diretor da George Eastman House, de Rochester ${ }^{80}$. A mostra não chegou a ser realizada ${ }^{81}$, no entanto, o envio da proposta já indica que a relação entre arte e fotografia vinha despertando interesse em diversos círculos, especialmente em função dos desenvolvimentos mais recentes da arte contemporânea.

Somente seis anos após o contato com Beaumont Newhall o MACUSP iria realizar sua primeira exposição de fotografia. Tratava-se de uma individual de Lenita Perroy, ${ }^{82}$ que apresentou 57 retratos de mulheres. $\bigcirc$ texto de apresentação do catálogo é de Wesley Duke Lee que assim descreve o processo de trabalho de Perroy:

Num ritual contínuo de metamorfoses, aplicou suas máscaras no contexto do mundo. Assim, construiu personagens, espectros de beleza imóvel foram se definindo cada vez com mais clareza. Suas aparições, vindas da artista, exercem o fascínio de um abismo magnético sobre um número crescente de mulheres que se iam submetendo à violação de suas personalidades cotidianas, endossando submissas as máscaras de beleza polar que a artista thes aplicava. Medusa, Lenita petrificou muheres em fotos feitas de mármore frio. Para transcender o monótono cotidiano de suas aparências, pagaram alto o preço de suas petrificações ${ }^{83}$.

Wesley Duke Lee alude ao processo de transformação pelo qual passaram as modelos de Lenita Perroy, que, submetidas a um jogo proposto pela fotógrafa, teriam sido petrificadas para sempre na imagem fotográfica, daí o nome da exposição. Alguns dos títulos das fotos trazem apenas um nome de mulher, outros apresentam um nome seguido de um subtítulo, que tanto pode aludir a um personagem quanto a um objeto de destaque na caracterização das modelos. As fotografias, ampliadas em três tamanhos, foram montadas em forma de poster, ou seja, adesivadas sobre suporte rígido ${ }^{84}$. Essa opção mostra que não havia preocupação em seguir o cânone museológico moderno, já consagrado para exposições fotográficas, com a utilização de passe-partouts e molduras. Ao contrário, havia o propósito claro de transgredi-lo. A exposição, ainda de acordo com depoimento de Walter Zanini, foi fechada pelos militares ${ }^{85}$ e não resultou na incorporação de obras ao acervo do Museu (Figura 4).

Nos dois anos que se seguiram à mostra de Lenita Perroy, a fotografia ganhou espaço significativo no Museu de Arte Contemporânea da USP. Entre maio e junho de 1970, o MAC apresentou a exposição Cartier-Bresson, fotografias recentes, organizada pelo MoMA, com curadoria de John Szarkowski,

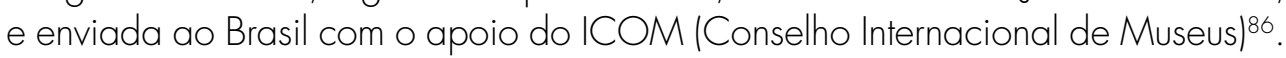
Essa mostra havia sido apresentada originalmente no MoMA, em 1968. A maioria das fotos foram produzidas na década anterior, sendo que um grupo de 30 imagens formava uma retrospectiva de trabalhos produzidos entre 1929 e 


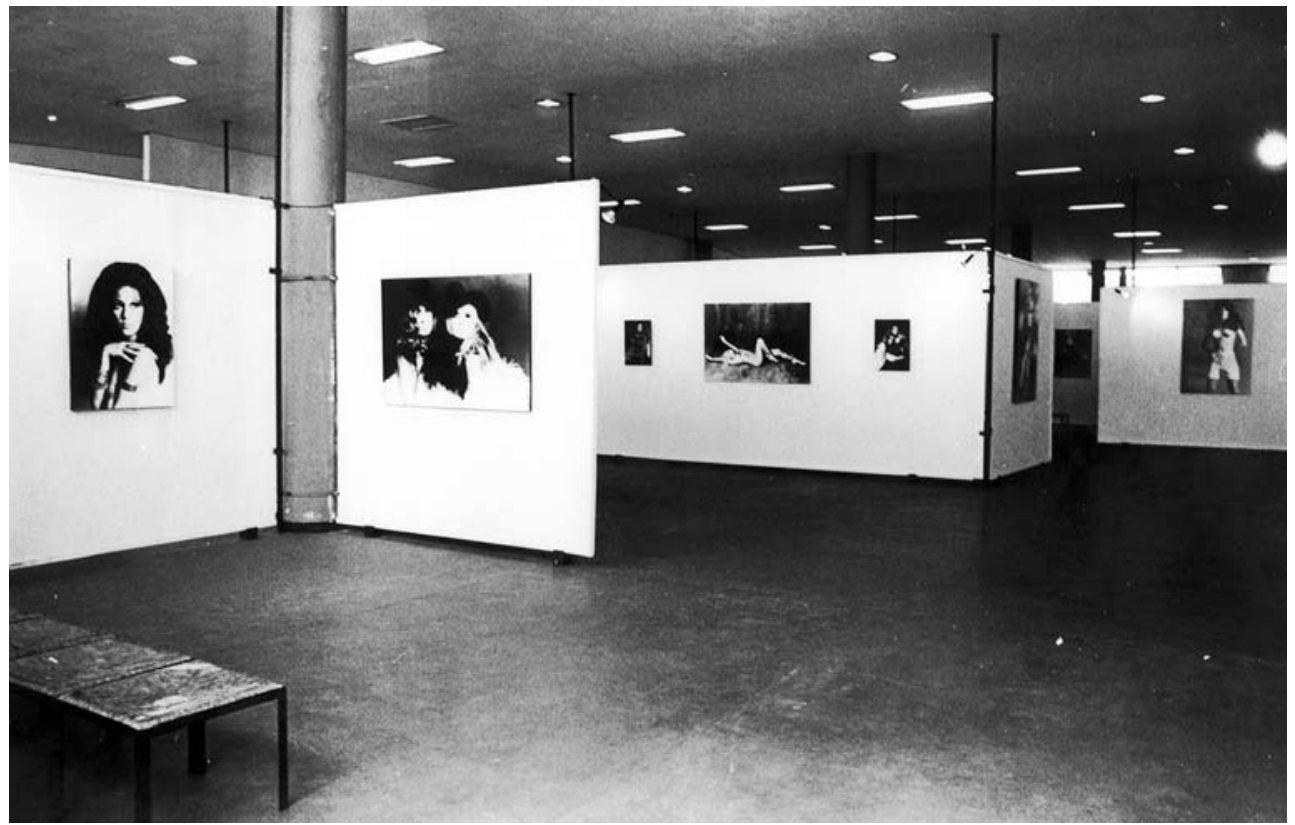

Figura 4 - Exposição Beleza de Pedra, 1969. Museu de Arte Contemporânea, Universidade de São Paulo. Arquivo MAC-USP.

195087. Os contatos preliminares para a itinerância dessa mostra no Brasil foram estabelecidos por Aracy Amaral ${ }^{88}$. Em correspondência endereçada a Walter Zanini, enviada de Nova York em novembro de 1969, Amaral descreve seu encontro com Waldo Rasmussen, então diretor-executivo do Departamento de Exposições Itinerantes do MoMA: "Ele e sua assistente me contaram então que justamente receberam pedido recente para envio de mostras para S.Paulo ao MAM daí e da Fundação Bienal (Matarazzo). Expliquei-the, então, a significação de cada uma dessas entidades no contexto cultural de São Paulo e a importância do MAC" 89

Este trecho da carta de Aracy Amaral demonstra que havia concorrência entre as instituições paulistanas para o recebimento das mostras itinerantes organizadas pelo Museu americano90. A exposição Cartier-Bresson, fotografias recentes apresentou 151 fotografias, em formatos e tamanhos variados, montadas em molduras de alumínio e protegidas com plexiglass, sem passe-partout, distribuídas em diferentes agrupamentos nas paredes (Figura 5). $\bigcirc$ MoMA enviou, além das fotos, as instruções para montagem, o título, os textos do curador (abertura e quatro textos de parede) e o do fotógrafo ${ }^{91}$. CartierBresson aproveitou a oportunidade para explicitar o seu conceito de instante decisivo sem, no entanto, nomeá-lo desta foma.

No meu modo de ver a fotografia nada mudou desde a sua origem, exceto nos seus aspectos técnicos os quais não são minha preocupação principal. A fotografia é uma operação instantânea que exprime o mundo em termos visuais, tanto sensoriais como intelectuais, sendo com várias instituições americanas, bem como com historiadores e teóricos da fotografia, entre os quais o próprio Newhall, Grace M.Mayer, Van Deren Coke e Heinrich Schwartz. MACUSP. Boletim Informativo, São Paulo, n. 9, 23 julho 1963. Essas correspondências não foram encontradas. Também não foi possível localizar documentos acerca do projeto da exposição dos motivos que inviabilizaram a sua realização no Brasil; ou, mesmo, se chegou a ser montada no exterior.

82. Os dados biográficos disponíveis sobre Lenita Perroy (nome artístico de Maria Helena Ribeiro Perroy) são esparsos. No catálogo da exposição, consta que formouse em Engenharia Elétrica pela Escola Politécnica da USP; atuou como assistente no estúdio de publicidade de Marcel Giró em São Paulo em 1961; trabalhou para o jornal $A$ Gazeta entre 1964-1965, como correspondente nos EUA e no Japão; e que voltou ao Brasil em 1966, quando passou a trabalhar para a revista de moda Jóia. Maria Helena casou-se com Olivier Perroy, adotando o sobrenome do marido e assumiu o codinome artístico de Lenita Perroy. Algum tempo mais tarde, iria abandonar a atividade fotográfica. Há notícias de que nos últimos anos tem se dedicado à administração de um haras no interior de São Paulo. Ver: MAC-USP, Beleza de Pedra: catálogo de exposição, 1969. Arquivo MAC-USP; e, também, MAC-USP. Boletim Informativo, São Paulo, n. 111, 27 mar. 1969. Agradeço aos pesquisadores Rubens Fernandes e Ricardo Mendes pelas informações complementares a estas fontes.

83. Wesley Duke Lee, Apresentação. In: MAC-USP, $B \boldsymbol{e}$ leza de Pedra: catálogo de exposição, 1969. Arquivo MAC-USP. 
84. Grandes: $1,46 \mathrm{~m}$ x 0,96m / Médias: $1,00 \mathrm{~m} \times 0,70 \mathrm{~m}$ / Pequenas: $0,50 \mathrm{~m} \times 0,60 \mathrm{~m}$. Ver: MAC-USP. Beleza de Pedra: catálogo de exposição, 1969. Arquivo MACUSP.

85. Não foi encontrada documentação acerca do fechamento da exposição de Lenita Perroy pela ditadura militar nos arquivos do MAC-USP. Nas fotos do espaço expositivo, observa-se que havia alguns nus entre os retratos, o que pode ter sido eventualmente um dos motivos para a censura da mostra. Lista completa de obras pode ser encontrada em MAC-USP. Beleza de Pedra: catálogo de exposição, 1969. Arquivo MAC-USP

86. Walter Zanini (1970). Ver também correspondência do MoMA, datada de 24 fev. 1970. Pasta 0154/02 v.2. Arquivo MAC-USP.

87. Pasta V.95.1/ICE-F-13068. Arquivo MoMA.

88. MAC-USP. Cartier-Bres son, fotografias recentes: catálogo de exposição, 1970. Arquivo MAC-USP. Consta nos arquivos do MAC que Aracy Amaral foi contratada pelo Museu de Arte Contemporânea como Assistente de Administração entre 1964-1965 e, posteriormente, nos anos de 1966 e 1969 , prestou serviços ao Museu sem vínculo empregatício. Anos mais tarde, en tre 25-11-1982 e 21-11-1986, viria a ser diretora da instituição. Levantamento realizado por Silvana Karpinsky, responsável pelo Arquivo do MAC-USP, em novembro de 2007

89. Correspondência de Aracy Amaral endereçada a Walter Zanini, datada de 14 de novembro de 1969. Pasta 0154/001 v.1. Arquivo MAC USP

90. Amaral não cita que o Museu de Arte de São Paulo também estava nesta dispu- também uma procura e uma interrogação constantes. É ao mesmo tempo o reconhecimento de um fato numa fração de segundo e o arranjo rigoroso de formas percebidas visualmente, que conferem a esse fato expressão e significado.

A exposição posteriormente itinerou por Brasília, Rio de Janeiro e Belo Horizonte, por iniciativa do diretor do MAC-USP92. A partir do contato feito naquela ocasião, Cartier-Bresson doaria ao Museu, em 1973, uma foto de sua autoria, assinada e com dedicatória no verso.

A excelente repercussão da exposição de Cartier-Bresson, que em parte pode ser aferida pelos inúmeros e elogiosos artigos publicados na imprensa ${ }^{93}$, motivou o diretor do MAC a designar, no mês de julho de 1970, uma comissão que seria encarregada de estruturar um Setor de Fotografia no Museu.

O Prof. Zanini propôs seja constituído no MAC um setor de fotografias, com assessoramento das diferentes entidades de classe, visando à constituição de um acervo, à realização de exposições e outras iniciativas culturais, tendo como objetivo o desenvolvimento da fotografia em nosso meio. A proposta foi aprovada, sugerindo os conselheiros que fôsse procedida a sua regulamentação ${ }^{94}$.

Os membros que vieram a constituir a comissão, além do próprio Walter Zanini, foram: Derli Barroso (Fundação Álvares Penteado) e Cláudio Araújo Kubrusly (Enfoco), como representantes das escolas; Thomaz Farkas, José

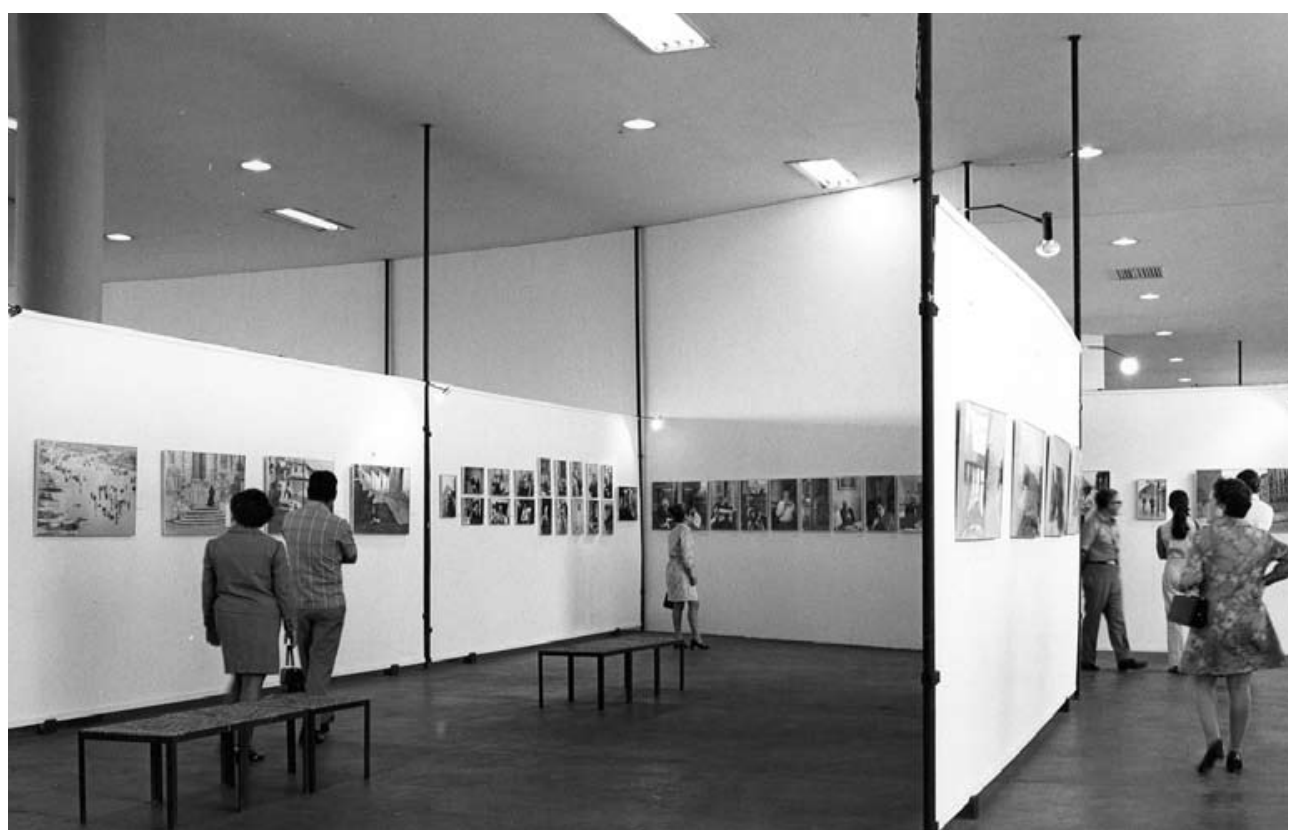

Figura 5 - Exposição Cartier-Bresson: fotografias recentes, 1970. Museu de Arte Contemporânea, Universidade de São Paulo. Arquivo MAC-USP. 
Xavier, Lenita Perroy, George Love, Claudia Andujar e Maureen Bisilliat, como representantes dos fotógrafos; e Eduardo Salvatore, que figurava na representação dos fotógrafos amadores ${ }^{95}$.

A primeira grande iniciativa do grupo seria a organização da exposição 9 Fotógrafos de São Paulo, em maio de 1971, que reuniu 86 fotos de autoria de alguns dos membros da própria comissão e de fotógrafos convidados 96 . Fizeram parte da mostra: Claudia Andujar, Maureen Bisilliat, George Love, Derli Barroso, Boris Kossoy, Cristiano Mascaro, Miguel Anselmo Viglioglia, José Xavier e Aldo Simoncini ${ }^{97}$. Walter Zanini, em seu texto de apresentação, situou a exposição no contexto das atividades desenvolvidas pelo Museu em relação à fotografia e afimou ser ela uma versão modificada de uma mostra realizada no Museu de Arte Contemporânea do Paraná em outubro do ano anterior.

A exposição de Henri Cartier-Bresson em maio de 1970, no Museu de Arte Contemporânea da Universidade de São Paulo, ensejou a aproximação deste instituto com inúmeros fotógrafos e associações de classe. Um painel de debates foi realizado a 3 de junho de 1970 no auditório do Museu, seguindo-se um encontro do qual participaram diversos representantes de entidades e escolas de fotografia, constituindo-se uma coordenadoria. Várias sugestões foram aprovadas e sobretudo as que dizem respeito à formação de um acervo de fotografias e a realização periódica de exposições. Em outubro de 1970 decidia o MAC enviar uma delegação de fotógrafos como representante do Estado à III Exposição Nacional da Associação dos Museus de Arte do Brasil (AMAB), promovida em Curitiba pelo Museu de Arte Contemporânea do Paraná, mostra agora trazida para a nossa sede com algumas alterações e acrescidas de alguns artistas. Trata-se de mais um passo do Museu nos seus objetivos de estimular as possibilidades de expressão artística da fotografia ${ }^{98}$.

Na exposição, os nove fotógrafos expuseram trabalhos muito diferentes entre si do ponto de vista da temática. Essa diversidade aparece, às vezes, nos conjuntos de fotos pertencentes a um mesmo fotógrafo, como no caso de Claudia Andujar, que apresentou três fotos intituladas Mulher Xincrin, juntamente com a obra Inês, objeto elaborado com fotografia, madeira e acrílico que hoje faz parte do acervo do MAC-USP99. Algumas imagens foram apresentadas na exposição em forma de poster e outras emolduradas com passe-partout e moldura, de acordo com a preferência e/ou disponibilidade de recursos de cada participante (Figura 6).

Cristiano Mascaro, por sua vez, apresentou vinte fotografias produzidas durante viagem que realizou a Bolívia, pela revista Veja, onde registrou flagrantes da comoção popular durante o enterro do presidente René Barrientos, em 1969100. As imagens, de pequeno formato, montadas em forma de poster, ressaltam a expressão de dor dos personagens em trajes de luto.

Já Boris Kossoy apresentou dez imagens de seu ensaio Viagem pelo fantástico, publicado em livro naquele mesmo ano ${ }^{101}$. ta. O MASP chegou a receber na ocasião várias mostras enviadas pelo MoMA, e não apenas de fotografia, dentre as quais podemos citar New photograpby: USA (1970); Four contemporary masters (1973) e Colour as language (1975). Pastas V.94.9; V.101.1; V.104.2. Arquivo MoMA.

91. O catálogo da exposição apresenta lista completa de obras, além de textos de Walter Zanini, John Szarkowski e do próprio CartierBresson. Pasta 0154/01, v.2. Arquivo MAC-USP.

92. A exposição itinerou pelas seguintes instituições Universidade de Porto Rico (fev. 1970); MAC-USP (maiojun. 1970); Centro Cultural do Distrito Federal, Brasília (jun.-jul. 1970); MAM-RJ (jul.-ago. 1970); Universidade Federal de Minas Gerais, Belo Horizonte (ago.-set 1970) e Centro de Arte e Comunicação, Buenos Aires (jul.-ago. 1971). V.ICE-F-13068.1. Arquivo MoMA.

93. Uma das matérias publicadas comenta a visitação da mostra: "[...] no Museu de Arte Contemporânea da Universidade de São Paulo as fotos de Cartier-Bresson estão tendo um número incrível de visitantes. [...] Desde sábado último o número de visitantes que percorreu a mostra foi superior a três mil pessoas e o afluxo continua bem grande". $\mathrm{FO}$ lba da Tarde, São Paulo, 21 maio 1970.

94. Ata da reunião do Conselho Deliberativo do MACUSP realizada em 15 de junho de 1970. Eram membros do Conselho, na ocasião: Anésia Pacheco e Chaves, José Geraldo Vieira, Mário Guimarães Ferri, Sanson Flexor e Eduardo Marques da Silva, além do diretor do MAC.

95. MAC-USP. Boletim Informativo, São Paulo, $\mathrm{n}$. 133, 21 ago. 1970. 
96. Essa exposição aparece como 9 Fotógrafos de São Paulo em alguns artigos, notas e no próprio espaço expositivo. No entanto, no catálogo, a exposição consta como Fotógrafos de São Paulo.

97. O catálogo da exposição apresenta um pequeno currículo de cada fotógrafo, além de lista de obras. Claudia Andujar aparece creditada como Claudia Andujar Love. Na época, a fotógrafa era casada com George Love. Arquivo MAC-USP.

98. MAC-USP. Fotógrafos de São Paulo: catálogo de exposição, 1971. Arquivo MAC-USP. Não foi possível localizar documentos sobre a exposição realizada em Curitiba.

99. Nesta exposição, Andujar apresentou ao todo cinco obras, sendo uma delas Sem título.

100. Mascaro tinha 27 anos na ocasião, havia se formado há três na Faculdade de Arquitetura e Urbanismo da USP, e fora aluno de José Xavier, fotógrafo também integrante da mostra.

101. O ensaio completo foi publicado no livro de mesmo nome. Ver Boris Kossoy (1971). Recentemente a obra fotográfica de Boris Kossoy foi objeto de uma exposição retrospectiva - $O$ caleidoscópio e a câmera na Pinacoteca do Estado de São Paulo, 25 de jan. a 30 de mar. de 2008. Mais informações sobre a obra de Boris Kossoy em <http://www. boriskossoy.com/>

102. Depoimento público de Boris Kossoy, fornecido à autora em aula do Curso de Especialização em Museus de Arte, do Museu de Arte Contemporânea da USP no primeiro semestre de 2005 .

103. Para o acervo do MAC, foram adquiridas fotografias

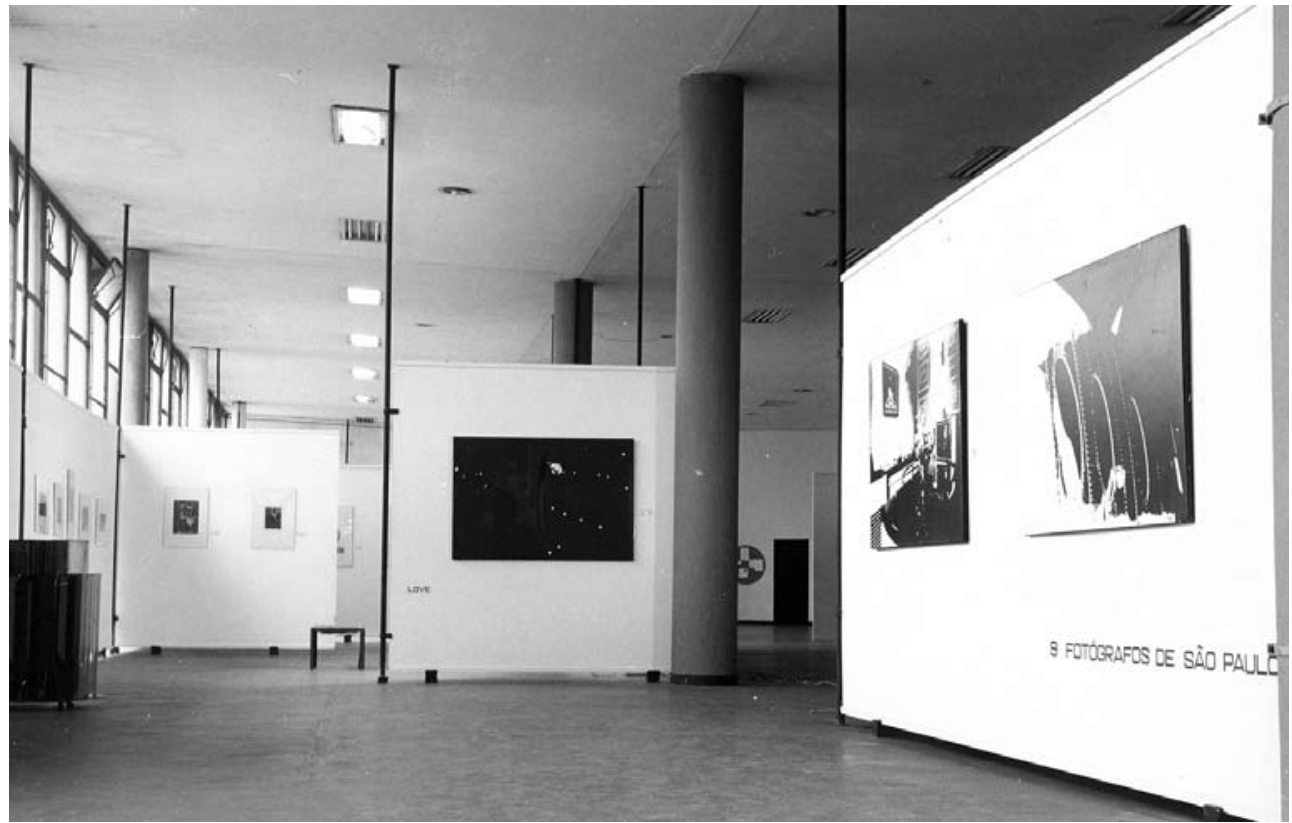

Figura 6 - Exposição 9 Fotógrafos de São Paulo, 1971. Museu de Arte Contemporânea, Universidade de São Paulo. Arquivo MAC-USP.

A série pretendia criar a possibilidade de duas realidades aparentemente distintas poderem conviver em uma mesma imagem. O princípio do fantástico reside muito nessa possibilidade. Não é nada sobrenatural, mas algo que foge do cotidiano ou daquilo que nos é familiar, ou ainda daquilo que poderia estar ou deveria estar acontecendo, segundo tais e tais regras da natureza ou impostas pelos homens. De repente há alguma coisa que se quebra, há uma fratura nesse nosso sistema mental de ver o mundo. Eu andava em busca dessa fratura, se é que isso era possível, e de como poderia registrá-la. [...] No ano de 1970 eu tinha que falar alguma coisa sobre o momento que se vivia. [...] E pensei que isso poderia ser feito como uma metáfora visual. A quantidade de pessoas que desapareciam e morriam nos porões do DoiCodi e o que acontecia no resto do país era algo assombroso ${ }^{102}$.

fotógrafo recorreu à encenação para criar imagens inusitadas alusivas à ditadura militar, subvertendo a verossimilhança da documentação fotográfica tradicional. Em seu ensaio, Kossoy aproxima-se assumidamente do realismo fantástico, com o qual tivera contato via literatura de Jorge Luis Borges e Julio Cortázar. São imagens enigmáticas que, segundo o autor, foram pouco compreendidas na época.

Logo após a mostra Fotógrafos de São Paulo, o Conselho Deliberativo do Museu de Arte Contemporânea aprovou destinação de verba para a compra de algumas das fotografias recém-expostas para integrarem o acervo do Museu, prática, ao que parece, atípica no Brasil naquela ocasião ${ }^{103}$. Além disso, três dos nove fotógrafos doaram espontaneamente algumas obras ${ }^{104}$. Estas aquisições e doações marcaram o ingresso da fotografia no acervo do MAC-USP e motivaram a criação de uma sala permanente para exposições de fotografia, 
inaugurada em 1971 105. A imprensa não deixaria de noticiar a inauguração do novo espaço do MAC, em uma matéria sobre a inusitada presença da fotografia nos museus de arte da cidade.

Nos museus, os novos vizinhos de Van Gogh e Renoir. As pessoas já não se assustam mais ao encontrar, no Museu de Arte de São Paulo, fotos de Claudia Andujar ou George Love expostas ao lado das telas de Van Gogh ou Renoir. Agora, um outro museu, o de Arte Contemporânea da USP, montou uma sala especial para a fotografia. $O$ professor Walter Zanini, diretor do MAC, explica porque resolveu criar esse acervo: - Desde que promovemos a exposição com fotos de Cartier-Bresson estamos sentindo o grande interesse das pessoas pela fotografia. Em junho de 1971, fizemos nova exposição, apresentando trabaIhos de nove fotógrafos de São Paulo. Justamente a partir dessa exposição é que foi criado o acervo de fotografia do MAC, que hoje tem obras de bons fotógrafos brasileiros e estrangeiros $^{106}$

No final do ano de 1972, seria a vez de o MAC apresentar a exposição $\bigcirc$ fotógrafo desconhecido, organizada por uma comissão composta por Walter Zanini, Maureen Bisilliat, Claudia Andujar, George Love e Djalma Batista (Figura 7). A exposição partiu de uma convocatória para apresentação de trabalhos por parte de fotógrafos, profissionais ou amadores, cuja produção ainda não tivesse sido amplamente divulgada. Tratava-se, segundo Walter Zanini, "da produção fotográfica anônima, ou seja, do fotógrafo que nunca ou raramente teve ocasião de exibir ou publicar suas obras" 107.

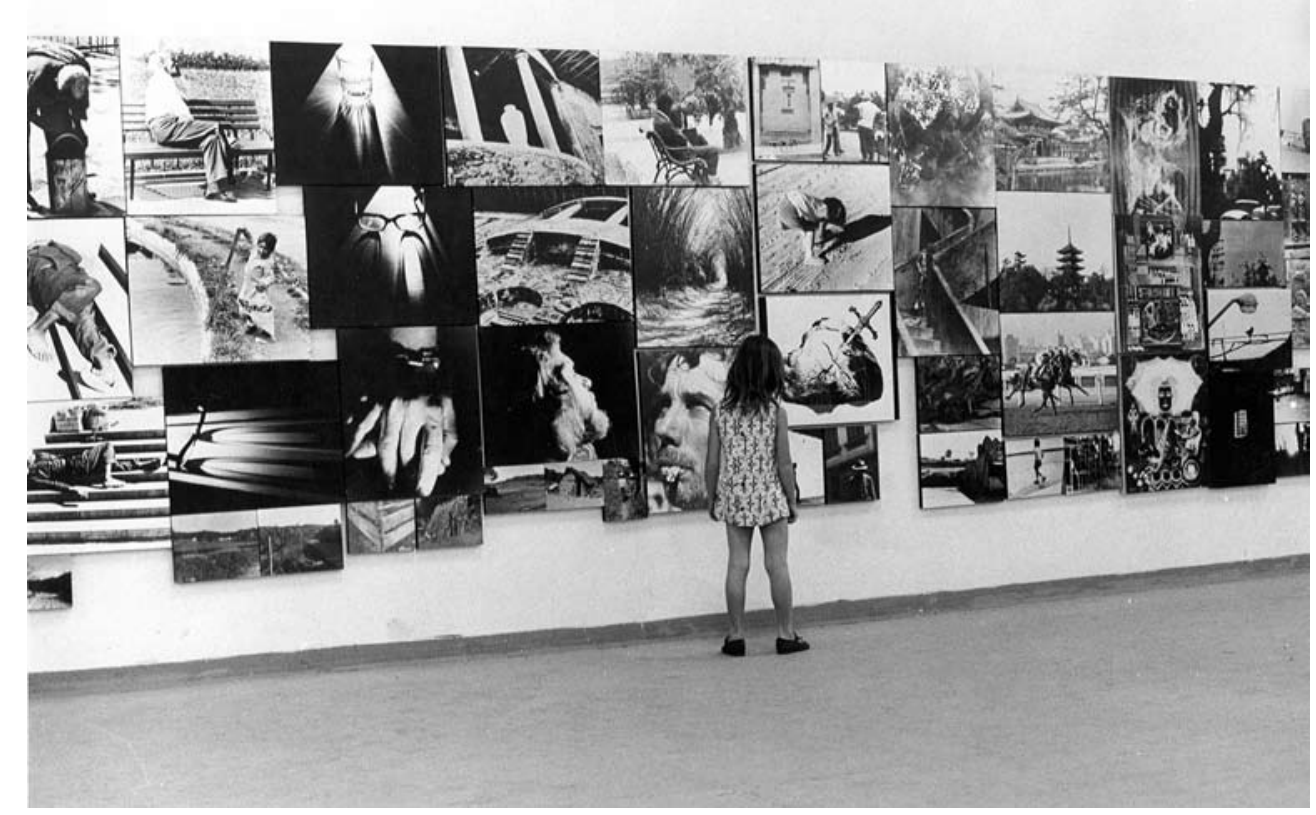

Figura 7 - Exposição $\bigcirc$ fotógrafo desconhecido, 1972. Museu de Arte Contemporânea, Universidade de São Paulo. Arquivo MAC-USP. de Maureen Bisilliat, Cristiano Mascaro e Claudia Andujar. Ver MAC-USP. Boletim Informativo, São Paulo, $\mathrm{n}$ 149, 30 jun. 1971; MAC-USP. Boletim Informativo, São Paulo, n. 158, 10 set. 1971. Em sua dissertação, Carolina Coelho Soares (2006, p. 66) reproduz texto de um folheto do MASP, veiculado por ocasião da criação do Departamento de Fotografia do Museu em 1976, no qual Pietro Maria Bardi afirma ter destinado verba para aquisição de fotografias para o acervo sem, no entanto, especificar a data.

104. Doadores: Boris Kossoy, George Love e Aldo Sinoncini. MAC-USP. Boletim Informativo, São Paulo, $\mathrm{n}$. 153, 7 ago. 1971.

105. "Com as aquisições e doações de 1971, o setor de fotografia teve seu acervo alargado, apresentando o MAC, em caráter permanente, uma sala de exposições de fotografia". Cf. Relatório de Atividades do MAC em 1971. MAC-USP. Boletim Informativo, São Paulo, $\mathrm{n}$. 165, 17 dez. 1971. Não foi possível descobrir até quando esse espaço foi mantido no MAC.

106. Todo mundo de câmera na mão. A nova mania é fotografar. Jornal da Tarde, São Paulo, 19 ago. 72. Pasta 0152/001. Arquivo MACUSP 
107. Walter Zanini. Introdução. In: MAC-USP. O fotógrafo desconbecido: catálogo de exposição, 1972. Arquivo MAC-USP.

108. MAC-USP. Boletim Informativo São Paulo, $\mathrm{n}$. 186, 18 nov. 1972.

109. Nestas listas podemos identificar alguns poucos nomes hoje reconhecidos na área de fotografia, não apenas como fotógrafos: Evandro Teixeira, Antonio José Saggese e Rubens Fernandes Júnior. Ver MACUSP. O fotógrafo desconbecido: catálogo de exposição, 1972. Arquivo MAC-USP

110. Walter Zanini. "Introdução”. In: MAC-USP. O fotógrafo desconbecido: catálogo de exposição, 1972. Arquivo MAC-USP.

111. Claudia Andujar. In MAC-USP. O fotógrafo desconbecido: catálogo de exposição, 1972. Arquivo MAC-USP.

112. Djama L. Batista. In: MAC-USP. O fotógrafo desconbecido: catálogo de exposição, 1972. Arquivo MAC-USP.

113. Pasta 0152/001. Arquivo MAC-USP,
Museu recebeu 266 inscrições para a exposição. A comissão organizadora decidiu aceitar todos os trabalhos inscritos, separando, no entanto, as fotos que considerava como "uma autêntica linguagem fotográfica", de outras que seriam indicativas de "índices criativos em processo"108. Isso resultou em uma lista de fotógrafos selecionados, e outra de fotógrafos participantes ${ }^{109}$. Segundo Walter Zanini, a exposição teria atingido dois objetivos principais:

1ํ) Revela uma série de desconhecidos que - não importa o código a que se relaciona sua imaginária - atingem o nível da linguagem fotográfica ou ao menos o grau da experiência pessoal em percurso de afirmação. 2| Demonstra, por vezes, na massa das participações, disponibilidades latentes ou embrionárias que poderão emergir, mas esta avalanche é válida essencialmente pelo relacionamento documental com o contexto cultural e social. Pode-se dizer que a natureza da manifestação impôs à comissão organizadora o dever de selecionar sem excluir. Cada um de seus membros assinalou com independência os trabalhos susceftíveis de uma apresentação particularizada no esquema da exposição - tarefa que exigiv esforços consideráveis ${ }^{110}$.

No catálogo da exposição cada um dos membros da comissão publicou um texto próprio, justificando sua posição quanto à supressão do processo de seleção e ao conjunto de imagens apresentado. É elucidativo avaliarmos ao menos duas dessas contribuições.

Particularmente acho-me mais envolvida em mostrar para o "grande público" o panorama de um esforço do que montar uma bela exposição, no sentido de exposição limpinha e bem arrumada. Por várias razões acho isso mais honesto, ou seja, levo em consideração as obras que se juntaram e a possibilidade de expô-las nos "halls" do MAC. Este esforço de busca, como o panorama da exposição demonstra, é um começo e não um resultado: é um incentivo para continuar. [...] Esta escolha é flexível, no sentido de que não pocuramos votar unanimemente em determinadas obras. Cada um apenas assinalou as que the pareceram melhores. Em particular, assinalei trabalhos que me tocaram mais profundamente pelo lado humano e que sinto serem realizações válidas dentro da linguagem fotográfica ${ }^{11}$.

Escolher entre centenas de fotos foi me angustiando. Em cada uma delas, observando atentamente, descobria o universo das pessoas: alegrias, tristezas, neuroses, limitações, repressões. Cada descoberta, por fazer parte de um jogo bastante fascinante, deixava-me perder um pouco os critérios de escolha. Só havia uma maneira de fazer esta escolha: objetivamente, tentando situar a foto a partir de sua proposição e da linguagem fotográfica utilizada para sua realização; a partir, principalmente, da própria foło e da linguagem de fotografia não tomada como "gramática" mas como possibilidade de múltipla escolha e de criação 112 .

A divergência de pontos de vista entre os textos publicados no catálogo, bem como a documentação do Arquivo do MAC-USP, indicam que não houve consenso entre os membros da comissão organizadora a respeito da inclusão de todas as fotos na exposição, apesar de esta opção ter prevalecido ${ }^{113}$. Em correspondência não datada, enviada a Walter Zanini, Maureen Bisilliat faz menção a uma reação intempestiva de sua parte durante o processo de avaliação 
das fotos, da qual se desculpa. No entanto, aproveita a ocasião para formalizar sua indignação com a solução adotada, que ela afirma ser: "um tanto depreciativa e nivelizadora [sic], que para um público pouco familiarizado com a linguagem plástica em geral e fotográfica em especial, seria, involuntariamente, desorientador - um tipo de 'fotocineclubebandeirante' de solarizações" 114.

○ comentário da fotógrafa reforça a análise que fizemos sobre o declínio do Foto Cine Clube Bandeirante, que se inicia nos anos 1960, e aponta para a vulgarização de certas soluções técnico-formais utilizadas freqüentemente pelos fotoclubistas, empregadas para se obter resultados fáceis, supostamente artísticos. Além disso, o tom irônico da carta denota a incompatibilidade de princípios que havia entre os membros da Comissão de Fotografia designada por Walter Zanini.

As obras reproduzidas no catálogo $\bigcirc$ fotógrafo desconhecido atestam que não foram enviadas apenas fotos diretas, mas também objetos que incluíam fotografias. A exposição contou com uma montagem arrojada, não uniforme, que contemplou imagens em forma de poster, distribuídas lado a lado, sem espaçamento; fotos, com ou sem passe-partout, fixadas diretamente na parede, de modo informal; e obras em suportes especiais (Figura 8). O MAC iria adquirir, pouco tempo depois, para o seu acervo, obras de sete dos participantes dessa exposição ${ }^{115}$. A aquisição de parte das obras selecionadas já havia sido anunciada, como prêmio, no regulamento da exposição.

Ainda em relação a essa exposição, cabe tentar entender o contexto cultural em que surge a proposta de apresentar fotografias realizadas por

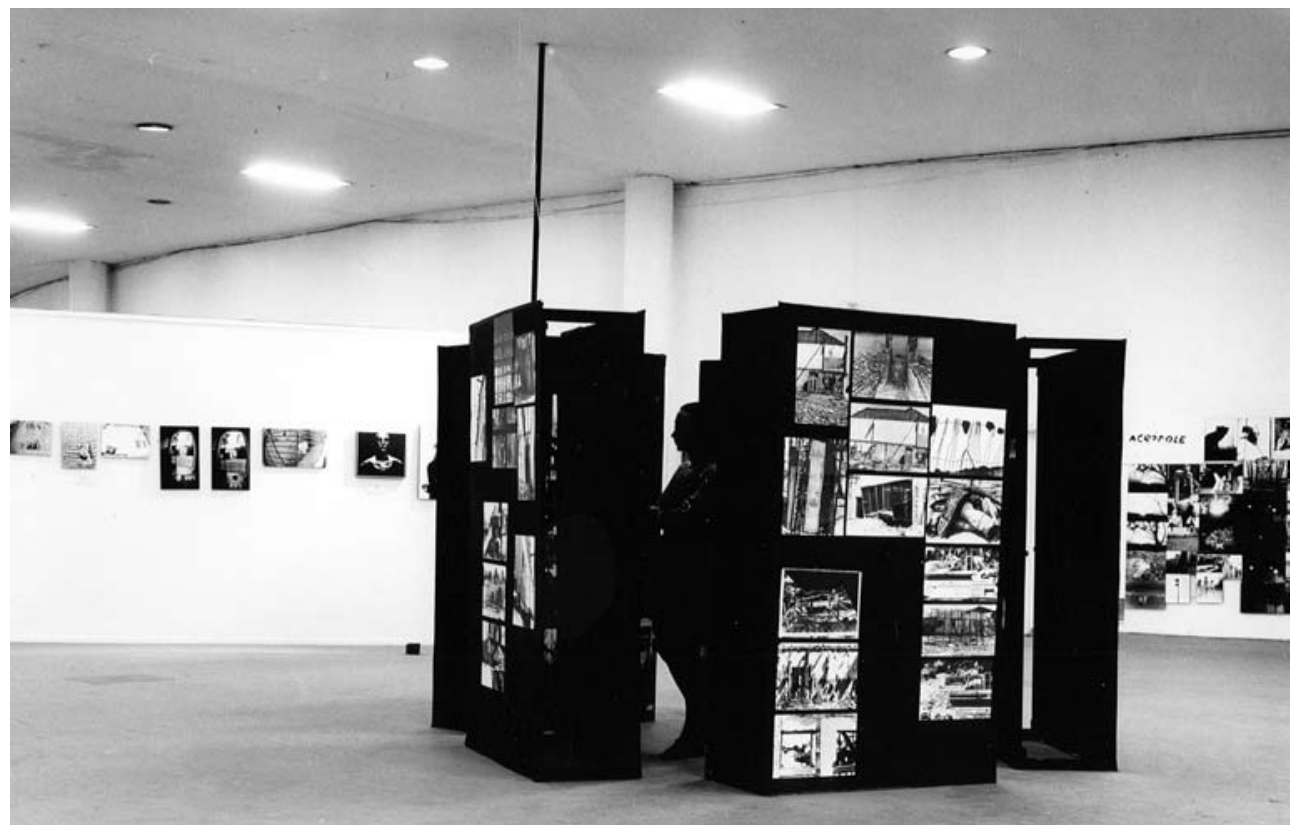

Figura 8 - Exposição $\bigcirc$ fotógrafo desconhecido, 1972. Museu de Arte Contemporânea, Universidade de São Paulo. Arquivo MAC-USP.
114. Ibidem.

115. Foram adquiridas obras dos seguintes fotógrafos: Paulo Cleto, Euclides Sandoval, Moema Cavalcanti, Marita Crespi, Ivan Kudrna, Antonio Carlos Antunes e Oswaldo T. Oyakawa. MACUSP. Boletim Informativo, São Paulo, n. 190, 19 dez. 1972. 
116. Ver John Szarkowski (1973; 2007). Essa idéia continua ainda hoje sendo retomada por críticos e curadores. Michel Frizot organizou, juntamente com Cédric de Veigy, o livro Pboto Trouvé, em que apresenta um grande conjunto de imagens produzidas por fotógrafos amadores anônimos. São imagens distantes dos cânones da fotografia artística consagrada e por isso mesmo muitas vezes surpreendentes e originais. Ver Michel Frizot \& Cédric de Veigy (2006). Recentemente, em julho de 2008, o MoMA apresentou, como aquisições recentes, 92 fotografias de fotógrafos anônimos produzidas entre 1900 e 1970 , cuja característica comum era a presença da sombra do fotógrafo na cena registrada. Curadoria de Peter Galassi, atual diretor do Departamento de Fotografia.

117. Walter Zanini. "Introdução". In: MAC-USP. O fotógrafo desconbecido: catálogo de exposição, 1972. Arquivo MAC-USP.

118. Ver Claudia Andujar (2005).

119. Ver correspondência de Walter Zanini, endereçada a Claudia Andujar e George Love, em que comenta viagem recente que havia feito a Nova York. Pasta 0152/001. Arquivo MACUSP

120. A exposição foi divulgada apenas como Fotógrafos contemporâneos, embora o título do catálogo inclua o número $\mathrm{V}$, referente ao programa do qual a exposição fazia parte em sua instituição de origem. Arquivo MAC-USP.

121. Ver pasta 05/204.1 Arquivo MAC-USP. Outras de fotos de Emmet Gowin acessíveis em <http://www.geh. org/ne/str085/htmlsrc5/index.html>. Acesso em novembro de 2008 . desconhecidos em um museu de arte. Nas décadas de 1960 e 1970, essa idéia era defendida por John Szarkowski, então curador do Departamento de Fotografia do MoMA. Esse tipo de produção, por ele denominada de vernacular, englobava a fotografia amadora e a fotografia comercial. De maneira mais precisa, pode-se afirmar que abarcava toda fotografia produzida sem finalidades artísticas, por aqueles que não detivessem conhecimentos de arte ou qualquer outro tipo de referência iconográfica especializada, fossem eles simplesmente desconhecidos ou efetivamente anônimos. A importância e originalidade da fotografia vernacular residiria, ainda segundo Szarkowski, em sua capacidade de colocar em evidência as características inerentes do medium, daí a importância de exibi-la em museus de arte ${ }^{116}$.

Não foi possível atestar uma filiação direta da exposição $\bigcirc$ fotógrafo desconhecido, realizada no MAC, com a posição do curador norte-americano. No entanto, algumas pistas devem ser consideradas. No texto de abertura do catálogo, Walter Zanini agradece a Claudia Andujar e George Love pela "colaboração teórica dada à formulação da exposição"117. Na biografia de Claudia Andujar, consta que ela se mudou para os Estados Unidos em 1946, onde permaneceu até 1955, quando então fixou residência no Brasil. Os anos passados em Nova York - quando, entre tantas outras atividades, cursou o Hunter College e a graduação em Humanidades na New York University - envolveram visitas freqüentes ao circuito de exposições e museus da cidade ${ }^{118}$. $\bigcirc$ mesmo se pode dizer a respeito da vivência de George Love em seu país natal antes de sua mudança para o Brasil. Sabemos, além disso, que Walter Zanini tinha estado na capital norte-americana em março de 1972 quando encontrou-se com diversos curadores, dentre os quais John Szarkowski ${ }^{119}$.

No ano de 1973 podemos destacar na programação do MAC-USP a exposição Fotógrafos Contemporâneos, enviada ao Brasil pela George Eastman House, de Rochester, por iniciativa de Beaumont Newhall, com o apoio do Serviço de Divulgação e Relações Culturais dos Estados Unidos. A mostra tinha como objetivo explorar "a diversificação de caminhos da expressão fotográfica no mundo de hoje", a fim de colocar o público "em contato com os trabalhos mais significativos da fotografia contemporânea nos Estados Unidos"120. Foram apresentadas 24 fotografias, de cinco jovens fotógrafos norte-americanos, pertencentes ao acervo do Museu de Rochester. Os selecionados foram Emmet Gowin, Gary Metz, David Ruether, Keite Smith e Michael Teres. Esses fotógrafos, pouco conhecidos na época - e mesmo hoje -, apresentaram cenas urbanas granuladas, semelhantes a gravuras, e imagens informes de borrões de luz sobre fundo negro, entre outras também distantes do formalismo e da fotografia documental humanista incentivada pelo MoMA na ocasião ${ }^{121}$. O perfil das fotos, aliado ao fato de se tratar de fotógrafos pouco conhecidos, talvez tenha sido determinante para a inexpressiva repercussão da mostra. Essa situação era previsível, a ponto de Claudia Andujar ter sugerido à direção do MAC que tentasse incluir na exposição os nomes de Eugene Meatyard, Les Krims, Kenneth Josephson e Nathan Lyons, a fim de conferir maior representatividade à mostra. Essa ampliação não foi possível devido à falta de patrocínio ${ }^{122}$. 
Larisa Dryansky ressalta a importância do Museu George Eastman naquele momento e afirma que seu papel na área de fotografia, nos Estados Unidos tem sido obliterado pela hegemonia conferida ao MoMA pelos pesquisadores do tema ${ }^{123}$. Segundo a autora, Nathan Lyons, conservador do Museu a partir de 1957, defendia a assimilação e a convivência de práticas fotográficas as mais diversas, o que teria resultado em uma situação peculiar para a instituiçãol24. "A abertura comandada por Lyons, seguida depois por seus sucessores diretos, permitiu a Rochester tornar-se, no início dos anos de 1970, um dos pontos de encontro entre a fotografia elaborada por artistas, que não se definiam a priori como fotógrafos, e o meio propriamente fotográfico" 125.

A possibilidade de encontros e trocas entre artistas e fotógrafos certamente era muito bem-vinda na gestão de Walter Zanini. No entanto, as fotografias expostas e o currículo dos partipantes mostram que a exposição não foi pautada por esse princípio. É preciso considerar, ainda, que Fotógrafos Contemporâneos era a quinta exposição de uma série concebida pelo Museu de Rochester e a única delas apresentada no Brasil. A apresentação isolada de uma exposição integrante de um conjunto maior também pode ter prejudicado a sua recepção local.

Quanto à importância do Museu George Eastman, devemos lembrar que ele foi criado como um museu de fotografia e não como um museu de arte, tipo de instituição que é objeto desta pesquisa ${ }^{126}$. Em que pese a argumentação de Dryansky, a afirmação da especificidade do medium, presente na própria natureza da instituição, parece ter sido um dos fatores limitadores do alcance de suas proposições no campo de discussão acerca da assimilação da fotografia pelos museus de arte.

No ano de 1974, o Museu de Arte Contemporânea voltaria a abrigar importantes exposições de fotografia. A primeira delas, Fotografia experimental polonesa, realizada em março de 1974, apresentou 38 obras de 22 autores ${ }^{127}$ (Figura 9). Pelo que pudemos levantar, os participantes da mostra eram fotógrafos e/ou artistas que, em sua maioria, tiveram significativa atuação na Polônia, nas décadas de 1960 e 1970, no âmbito da arte conceitual ${ }^{128}$. Segundo divulgação do MAC, eram "os mais destacados fotógrafos de vanguarda da Polônia, participantes de grupos de Cracóvia, Torun e Lodz, quase todos nascidos nas décadas de 20 e 30, geralmente de larga atuação inclusive no plano internacional"129. As obras, em sua maioria, conferiam um caráter objetual à fotografia por meio da aderência de imagens recortadas a suportes rígidos. Há ainda seqüências fotográficas e imagens que passaram por diversos tipos de intervenção. Logo após a mostra, os artistas doaram as 38 obras expostas ao acervo do MAC-USP por intermédio do Consulado Geral da Polônia ${ }^{130}$.

No mês de abril de 1974, o MAC-USP receberia uma nova exposição enviada pelo Museu de Arte Moderna de Nova York: 70 fotos de Brassaï (Figura 10). A mostra, com curadoria de John Szarkowski, apresentou fotografias do acervo do MoMA ao lado de fotos da coleção particular do próprio Brassaï. No texto do catálogo, Szarkowski defende a especificidade da fotografia.
122. A divulgação da exposição na imprensa foi pequena e restringiu-se a notas que reproduziam o texto de divulgação do MAC. Por sugestão de Claudia Andujar, o MAC encaminhou pedido de patrocínio à Fotóptica para trazer trabalhos dos fotógrafos citados, mas não foi atendido. Correspondência datada de 27 de junho de 1973. Pasta 053/01. Arquivo MAC-USP. Cabe considerar, também, o curtíssimo espaço de tempo em que a mostra ficou aberta ao público: apenas dez dias, segundo as datas publicadas no catálogo. Se analisarmos o período de cada uma das exposições de fotografia do MAC na década de 1970 , veremos que a duração média de cada uma delas era de vinte a trinta dias.

123. Cf. Larisa Dryansky (2007, p. 75-76).

124. Idem, p. 79. Segundo Larisa Dryansky, a partir do ingresso de Nathan Lyons como conservador, houve uma divisão de tarefas entre ele e Newhall: Lyon ficou responsável pela fotografia contemporânea, ao passo que Beaumont ficou encarregado da fotografia dita histórica.

125. Idem, p. 75.

126. O Museu George Eastman foi inaugurado em novembro de 1949, com a coleção de George Eastman, fundador da Kodak, e parte da coleção do francês Gabriel Cromer, membro da Sociedade Francesa de Fotografia, falecido em 1934. Cf. Larisa Dryansky (2007, p 75). Para um relato pormenorizado da criação do Museu e de suas atividades, ver Beaumont Newhall (1993, p. 190-228).

127. MAC-USP. Fotografia Experimental Polonesa: catálogo de exposição, 1974. Arquivo MAC-USP.

128. Dentre os participantes, 
destacam-se os nomes que se seguem, com uma atuação mais duradoura e significativa no contexto polonês, segundo a bibliografia levantada: Andrzej Lachowicz (integrante do grupo Permafo); Andrzej Rozycki, Antoni Mikolajczyk e Josef Robakowski (integrantes do grupo Zero-61), Edward Hartwig (desenvolveu um estilo gráfico que veio a influenciar inúmeros fotógrafos de paisagem na Polônia), Jerzy Lewczynski (caracterizou-se por trabalhar com "fotografias encontradas", atividade que mais tarde foi denominada de "arqueologia fotográfica"), Pawel Pierscinski, Wojciech Plewinski, Zbigniew Dlubak (pintor e fotógrafo) e Zofia Rydet (ligada inicialmente à vertente polonesa da fotografia sociológica, dedicou-se posteriormente a experiências fotográficas com múltipla exposição). $\mathrm{O}$ grupo Zero-61, a princípio, conjugou características pictorialistas com o experimentalismo modernista e acabou por incorporar influências dadaístas e da pop arte. De maneira geral estes fotógrafos trabalhavam com fotoobjetos, seqüências fotográficas e instalações com fotos. Ver: Krzysztof Jurecki ([s. d.]); e Adam Sobota ([s. d.]).

129. MAC-USP. Boletim Informativo, São Paulo, $\mathrm{n}$. 221, 1 mar. 1974.

130. MAC-USP. Boletim Informativo, São Paulo, $\mathrm{n}$. 232, 6 jun. 1974 .

131. MAC-USP. 70 fotos de Brassaï: catálogo de exposição, 1974. Arquivo MACUSP

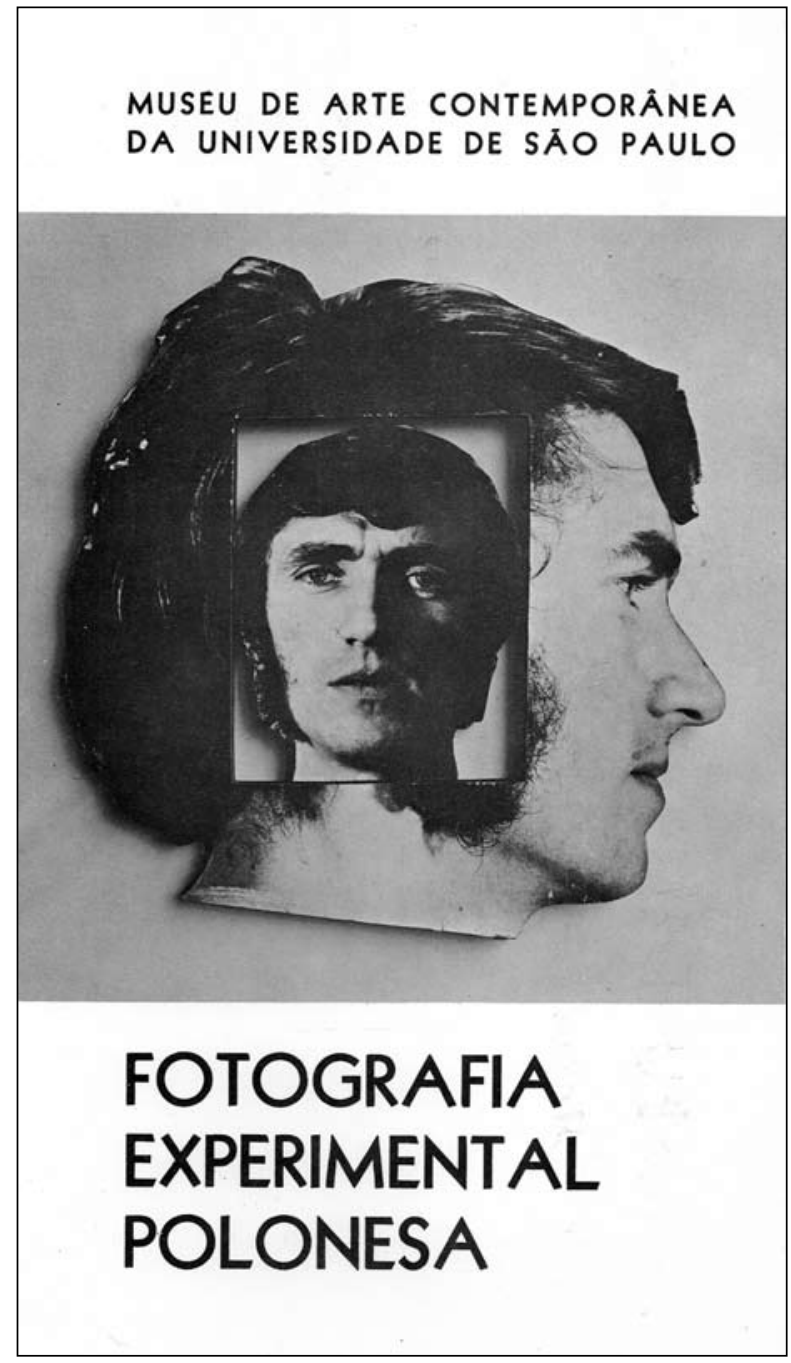

Figura 9 - Capa do catálogo da exposição Fotografia Experimental Polonesa, 1974. Museu de Arte Contemporânea, Universidade de São Paulo. Arquivo MAC-USP.

Sua técnica responde perfeitamente a sua visão. Suas fotos, à primeira vista primitivas, demonstram precisão e exatidão aos não familiarizados com elas. As formas, espaços e texturas de seus temas estão expressos com totalidade e unidade plástica. As fotografias de Brassaï não são "experimentais". Estão livres de refinamentos gratuitos e enfatuação com a fotografia como técnica. Não trazem à mente o ato de fotografar; é como se o sujeito reproduzisse a si mesmo, de alguma maneira que também the é inerente. Estas autoridade e dignidade profundas são a medida do gênio de Brassaiil ${ }^{31}$.

$\bigcirc$ fotógrafo é apontado como autor genial, que sabe fazer uso das potencialidades da fotografia direta e não se deixa levar pelos caminhos supostamente fáceis do experimentalismo. Em outubro do mesmo ano, uma exposição - Hildegard Rosenthal. Fotografias - produzida pelo MAC, viria 


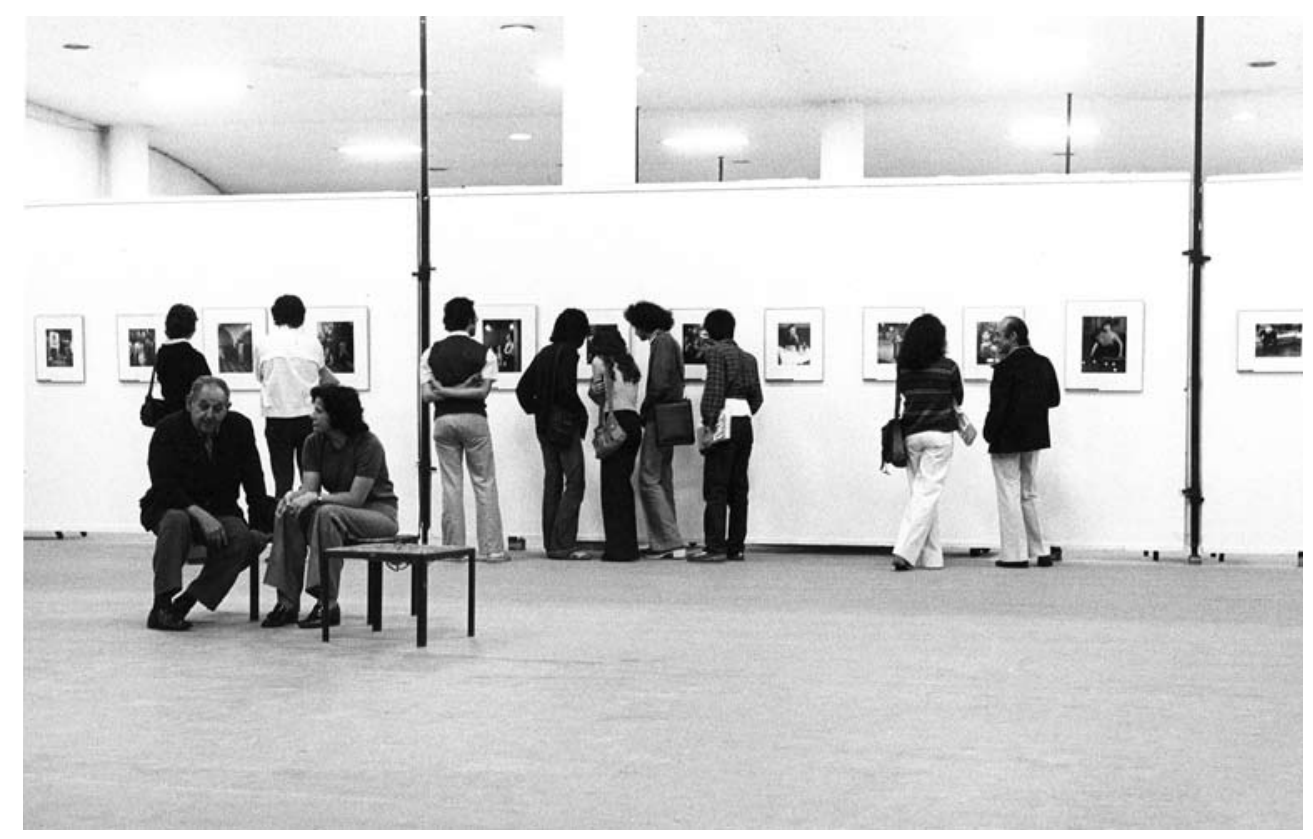

Figura 10 - Exposição 70 fotos de Brassaï, 1974. Museu de Arte Contemporânea, Universidade de São Paulo. Arquivo MAC-USP.

somar-se na valorização da fotografia direta de caráter autoral, ao reunir 82 imagens, distribuídas em nove séries, que mostravam cenas da cidade de São Paulo, aspectos da vida rural paulista, e retratos de artistas e intelectuais ${ }^{132}$.

Fotógrafa de origem alemã, Rosenthal chegou ao Brasil em abril de 1937, tendo logo começado a trabalhar para a imprensa ${ }^{133}$. Ao longo da década seguinte, desenvolveria intensa atividade na área, até abdicar da carreira, em 1948, para dedicar-se integralmente à criação das filhas. Hildegard passaria a produzir apenas retratos de seu núcleo familiar e de amigos próximos. Foi, portanto, após vinte e seis anos de ostracismo, que se realizou a exposição de Hildegard Rosenthal no MAC-USP, como a própria fotógrafa assinalou em seu depoimento ao Museu da Imagem e do Som em 1981. "Bom, quando eu era muito desconhecida e quase desprezada, baixou o Walter Zanini na minha casa [...]. Ele marcou hora, 9 horas. E foi indicado pela Yolanda Mohaly [...] queria ver umas fotografias. Ele entrou às $9 \mathrm{~h}$ e saiu às $3 \mathrm{~h}$ da madrugada. Porque ele viu tanta coisa, tanta coisa [...] o Zanini me descobriu"134.

De fato, a exposição individual de Hildegard Rosenthal no MAC foi um marco no reconhecimento da produção da fotógrafa pelo circuito local e vinha demonstrar o profundo desconhecimento que havia sobre a história recente da fotografia brasileira, como bem avaliou Walter Zanini.

O levantamento metódico da obra realizada pelos fotógrafos de São Paulo décadas atrás, é tarefa que aguarda cumprimento. Ao contrário da atenção devotada entre nós a outros setores tradicionalmente melhor reconhecidos da linguagem visual [...] a fotografia permanece

132. As séries expostas foram: Cidade de São Paulo, Flagrantes de São Paulo, Retratos, Artistas e ateliês, Brasil pitoresco, Pirapora, Professores no interior, São Miguel, e Plantação de chá Ver MAC-USP. Hildegard Rosenthal. Fotografias: catálogo de exposição, 1974. Arquivo MAC-USP.

133. Sobre a trajetória de Hildegard Rosenthal ver: Paula C. S. Gonçalves (2007). As informações contidas nesse parágrafo foram tiradas dessa monografia.

134. Apud Paula C. S. Gonçalves $(2007$, p. 136). Depoimento de Hildegard Rosenthal ao Museu da Imagem e do Som, 25 maio 1981. 
135. MAC-USP. Hildegard Rosenthal. Fotografias: catálogo de exposição. Arquivo MAC-USP.

136. Cf. Paula C. S. Gonçalves (2007, p. 109-110), a respeito das diversas exposições das quais Hildegard Rosenthal irá participar a partir de 1974

137. Harumi Yamagishi Multimídia III: release da exposição, 1976 (datilografado). Arquivo MAC-USP.

138. No Boletim que trata da exposição Multimedia III, consta que todas as obras expostas foram incorporadas ao acervo do $\mathrm{Mu}$ seu. Nem todos os artistas citados, no entanto, podem ser encontrados na coleção do MAC-USP. MAC-USP. Boletim Informativo, São Paulo, n. 300, 5 jun. 1976 .

139. Texto de Harumi Yamagishi. In: MAC-USP. Novos e novíssimos fotógrafos: catálogo de exposição, 1976. Arquivo MAC-USP. na longa expectativa do surgimento de pesquisadores. Certamente, o impulso atual dos estudos fotográficos, a abertura de escolas especializadas e a criação de disciplinas específicas em museus, produzirão motivações capazes de revelar atividades antepassadas. Um trabaTho necessário resta portanto a ser feito na descoberta de trajetórias, na recuperação de nomes e no selecionamento de documentos dispersos na grande malha da criação anônima. Ao apresentar esta exposição de Hildegard Rosenthal, fotógrafa residente nesta cidade desde 1937, o Museu de Arte Contemporânea procura trazer uma contribuição no sentido apontado ${ }^{135}$.

A exposição resultou na doação do expressivo conjunto de fotografias, selecionadas por Walter Zanini, ao acervo do Museu. As cópias fotográficas foram produzidas especialmente para a ocasião, com a supervisão da fotógrafa, a partir dos negativos originais. Daquela data em diante, Hildegard iria participar de inúmeras mostras, inclusive de duas edições da Bienal de São Paulo. A valorização de sua obra não deixaria de crescer desde então. Além da participação na XIV Bienal de Arte de São Paulo, em 1977, voltou a expor na XV Bienal em 1979136.

Para fecharmos o inventariamento das exposições de fotografia realizadas no MAC-USP na década de 1970, durante a gestão de Walter Zanini, cabe-nos ainda comentar três mostras.

Prosseguindo a série de exposições de arte conceitual, a Multimedia III concentrou-se mormente na fotografia. [...] Os artistas conceituais, em oposição à arte tradicional, na sua campanha de destituição do objeto estético e no encaminhamento à desmaterialização, apoiaram-se na pesquisa lingüística e semiológica e na aplicação de métodos de análise dessa ciência a seus propósitos. A fotografia, nesse caso, surge como um de seus recursos técnico-lingüísticos fundamentais ${ }^{137}$.

Na proposta dessa exposição, chama atenção o reconhecimento, já na época, da importância que a fotografia desempenhava na arte conceitual. Participaram da mostra Arthur Barrio, Regina Silveira, Regina Vater, Peter Vogel, e Willian Vazan, entre outros ${ }^{138}$ (Figura 11 ). Dois meses depois da realização de Multimedia III, outra exposição iria reiterar o viés experimental da fotografia. Apesar do título - Novos e novíssimos fotógrafos -, estava longe de ser uma exposição tradicional de fotografia.

Na atual manifestação verifica-se sempre a exploração do aspecto característico e inerente do próprio procedimento instantâneo de registro da fotografia ou ainda aparecem fotomontagens e fotos retrabalhadas utilizadas essencialmente para a transmissão de conceitos, extrapolando o nível exclusivamente estético. A foto não se situa no plano da arte pela arte mas se enquadra no âmbito das outras multimedias, relacionada com a informação e a comunicação. A colocação de questionamento, de investigação, de confrontações, de denotações, de analogias, de reflexões, ao nível da crítica, através da imagem fotográfica, predomina nos trabalhos aqui apresentados ${ }^{139}$. 


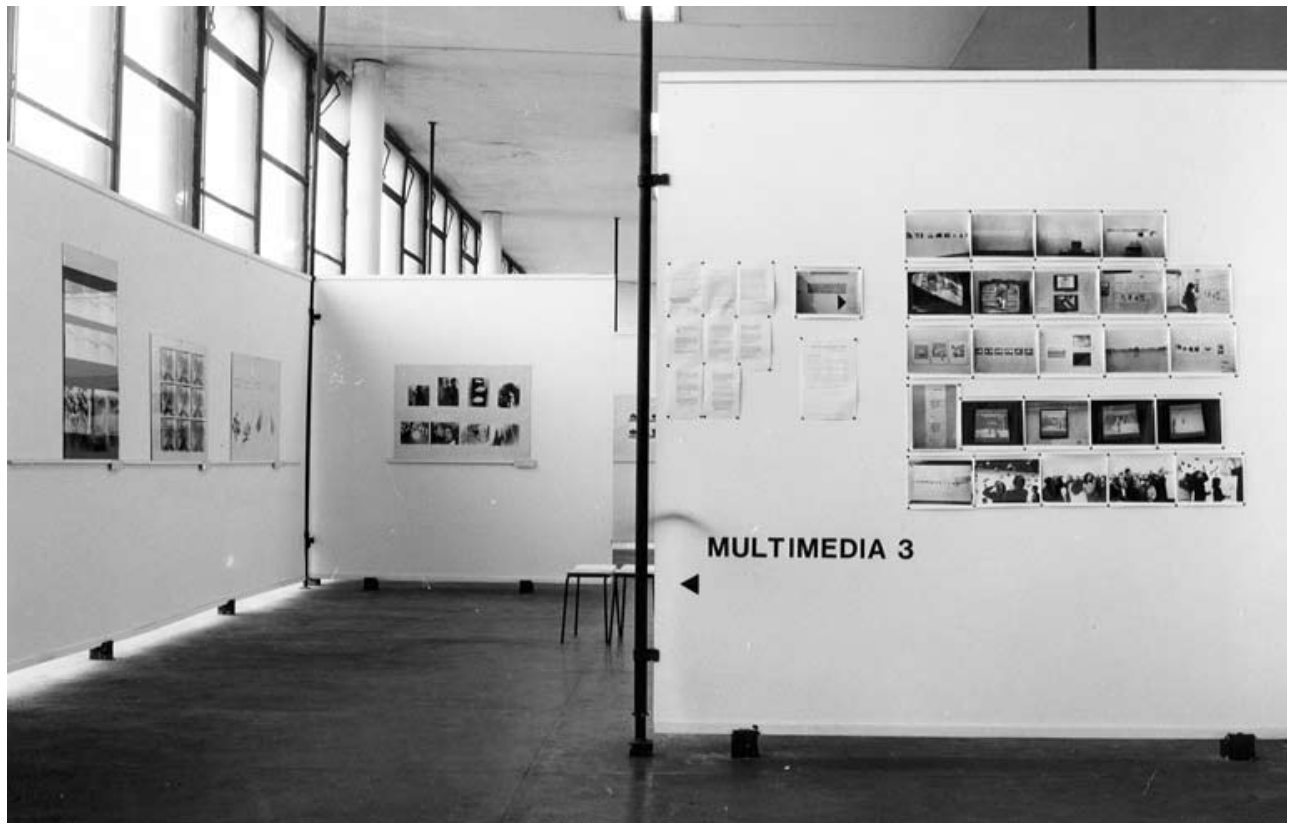

Figura 11 - Exposição Multimedia III, 1976. Museu de Arte Contemporânea da Universidade de São Paulo. Arquivo MAC-USP.

Novos e novíssimos fotógrafos reuniu 28 participantes, sendo a maioria de São Paulo. Entre eles, podemos citar Artur Matuck, Genilson Soares, Gerson Zanini, Harumi Yamagishi, Maurício Fridman, Paulo Klein, Percival Tirapeli e Rômulo Fialdini. Foram apresentadas, além de fotografias propriamente ditas, obras em xerox, áudio-visual e diapositivos ${ }^{140}$.

A última exposição de fotografia da gestão Zanini foi a individual de Dario Chiaverini, realizada em outubro de 1977. Jovem fotógrafo que havia participado da coletiva Novos e novíssimos fotógrafos no MAC, Chiaverini apresentou nessa ocasião algumas séries fotográficas, tendo comentando: "Não uso a fotografia para captar uma realidade através de momentos insólitos ou belos, mas como um processo de montar ou desmontar uma realidade" 141.

Como uma primeira conclusão sobre o processo de incoporação da fotografia ao acervo do MAC-USP na década de 1970, devemos assinalar que ele se materializou por meio das exposições realizadas no Museu. A única exceção parece ter sido o conjunto de fotografias de Alice Brill, adquirido em $1974^{142}$. No que se refere à produção fotográfica apresentada e incorporada ao acervo, ocorre uma abertura a diferentes tendências. Observa-se a assimilação do fotojornalismo e da documentação, como nos trabalhos de Cristiano Mascaro e Hildegard Rosenthal; dos ensaios fotográficos autorais, como em Boris Kossoy e Maureen Bisilliat, e da chamada fotografia experimental, representada por Anna Bella Geiger, Luiz Alphonsus, Arthur Barrio e Jean Otth ${ }^{143}$. Nessa última categoria, cabe ressaltar a incorporação de objetos fotográficos ao acervo, ou seja, de obras tridimensionais que incluem imagens fotográficas. Este foi o caso
140. NOVOS e novíssimos fotógrafos. MAC-USP. Boletim informativo, São Paulo, n. 311,16 out. 1976 . A lista de obras do catálogo não permite a identificação da técnica de todas as obras expostas.Ver MAC-USP. Novos e novíssimos fotógrafos: catálogo de exposição, 1976 (mimeo). Arquivo MAC-USP. Uma edição posterior do Boletim informa que Euclides Sandoval, Gastão de Magalhães e Maurício Fridman apresentaram áudio-visuais MAC-USP. Boletim Informativo, São Paulo, n. 313 , 27 out. 1976.

141. MAC-USP. Boletim Informativo, São Paulo, $\mathrm{n}$. 363, p. 2, 12 out. 1977.

142. O acervo do MAC-USP possui 107 fotografias de Alice Brill. Não foi possível levantar até o momento detalhes sobre como essas fotos entraram na coleção. No Arquivo do Museu, consta apenas que foram adquiridas em 1974, e não há nenhum Boletim Informativo que trate do assunto.

143. "O MAC acaba de adquirir diversas obras em diferentes técnicas para sua coleção nacional e estrangeira. Além de desenhos, pinturas, um álbum fotográfico de Luiz Alphonsus, o áudio-visual 'Circumambulatio' de Anna Bella Geiger e três áudio-visuais [...] de Barrio". Ver MAC-USP. Boletim Informativo, São Paulo, n.209-A, 1 set. 1973. Uma seqüência de fotos de Jean Otth, tomadas de televisores ligados, foram doadas ao MAC pela Bienal de São Paulo em novembro de 1973 . MAC-USP. Boletim Informativo, São Paulo, n.215-A, 14 nov. 1973. 
144. Também pertencente ao acervo do MAC-USP, a obra $O$ beijo, de Waldemar Cordeiro, datada de 1967 , pode ser enquadrada na categoria de objeto fotográfico. No entanto, ela só foi incorporada ao acervo em período posterior, a partir de doação da família Cordeiro. Arquivo MAC-USP.

145. Não encontrei justificativa para o envio ao MACUSP justamente dessas duas mostras individuais de fotógrafos europeus no arquivo do MoMA-NY.

146. Entrevista concedida à autora, em abril de 2006. Sobre o assunto, ver também trecho de carta de Walter Zanini a John Stringer, então diretor assistente do Programa Internacional do MoMA, desculpando-se pela retenção das fotos de CartierBresson na alfândega por ocasião da saída da exposição do Brasil: "It's quite clear that the bureaucratic obstacles are so heavy in Brazil that discouraged in receiving foreigner exhibition". Correspondência de 25 maio 1971. Pasta 0154/001, v.1. Arquivo MAC-USP

147. CONFER NCIA dos dirigentes de museus de arte do hemisfério em Nova York. In: MAC-USP. Boletim Informativo, São Paulo, n.167-B, p. 2, 29 mar. 1972 . Trata-se de relato de Walter Zanini sobre a X Conferência dos Diretores de Museus de Arte do Hemisfério, realizada en tre 5 e 7 de março de 1972. Arquivo MAC-USP.

148. O termo fotolinguagem foi utilizado por artistas e críticos do Rio de Janeiro, como Iole de Freitas e Roberto Pontual. A Nova Fotografia. Jornal do Brasil, Rio de Janeiro, 1 nov. 1976. Arquivo MAC-USP. Cf. também Roberto Pontual (1987, p. 424). de Inês, de Claudia Andujar, objeto projetado para ser fixado na parede, composto de foto e acrílico. Inclui-se também, aqui, diversas das obras que participaram da mostra Fotografia Experimental Polonesa ${ }^{144}$.

Devemos destacar a parceria do MAC-USP com o MoMA, para a realização das duas importantes exposições que investiram na afirmação do caráter artístico da fotografia documental humanista, representada por Henri Cartier-Bresson e Brassaii. Foi a exposição de Cartier-Bresson que abriu espaço no MAC para a formação da Comissão de Fotografia e, conseqüentemente, para a realização de várias das mostras fotográficas que se seguiram. O MoMA buscou, com essas duas exposições, exportar os critérios legitimadores para a fotografia artística adotada por seu Departamento de Fotografia, fundamentados na fotografia direta de caráter autoral ${ }^{145}$. Não por acaso, ambas as mostras apresentaram apenas vintage prints.

Não foi possível levantar os motivos que impediram a continuidade da colaboração entre o MAC-USP e o MoMA. No entanto, Walter Zanini é enfático ao descrever as inúmeras dificuldades que, no período da ditadura militar, o MAC tinha de enfrentar para a liberação das obras na alfândega ${ }^{146}$. Esse teria sido um dos fatores principais para a descontinuidade do intercâmbio, além das limitações financeiras do Museu, já que a vinda das exposição exigia gastos consideráveis.

Os dirigentes da América Latina fizeram sentir aos seus colegas norte-americanos a difuculdade representada pelas taxas por vezes muito elevadas, cobradas pelo MoMA, afora as despesas que devem atender para fins de transporte, seguro e impressão de catálogos. [...] Foram ainda discutidos problemas relativos à Alfândega, particularmente graves no Brasil, e que têm contribuído seriamente para a sua exclusão do roteiro das itinerantes ${ }^{147}$.

Em que pesem os esforços do museu americano para exportar o seu conceito de fotografia artística, o dado que me parece mais significativo em relação ao processo de assimilação da fotografia pelo MAC-USP é que ele ocorre a partir de duas frentes concomitantes: uma, a que investe na fotografia como linguagem autônoma; e outra, a que entende a fotografia no contexto das práticas artísticas contemporâneas, especialmente no âmbito da arte conceitual. Trata-se de duas instâncias de legitimação essencialmente antagônicas em suas premissas. De um lado, a fotografia considerada por suas qualidades estéticas; e, de outro, a fotografia inserida na discussão mais ampla da arte contemporânea, servindo como elemento crítico para problematizar a autonomia da obra de arte e os limites da representação. A primeira era a chamada fotografia de autor, ou fotografia artística, e a segunda, fotografia experimental ou fotolinguagem ${ }^{148}$.

$\mathrm{Na}$ verdade, se considerarmos todo o conjunto de exposições realizadas no MAC-USP na década de 1970, e não apenas as de fotografia, veremos que a segunda frente acabou por prevalecer. Exposições como a Jovem Arte Contemporânea (Jacs) ou Multimedia, em suas várias edições, apresentaram inúmeras fotografias e/ou obras que incluíam imagens fotográficas. Na época, 
Roberto Pontual chamou atenção para a importância desse fenômeno e sua atualidade, ao analisar a programação do MAC:

Quanto às amostragens especificamente experimentais da linguagem fotográfica, reuniu-as em mostras como Fotografia Experimental Polonesa (1974), Arte Catastrófica do Oriente (1975) e nas três Multimédia (1975/1976), observando-se também muitas propostas nesse sentido na sua Prospectiva-74. Um interesse suficientemente comprovado, portanto - e mais oportuno ainda quando se sabe o papel atualmente representado pela fotografia, com a sua conseqüente fotolinguagem, entre os meios de maior utilização entre os artistas nossos e de todo o mundo ${ }^{149}$.

Para justificar a desativação do Setor de Fotografia do MAC-USP, Walter Zanini relembra que tentou atrair para o museu profissionais da área, de diferentes segmentos, que pudessem levar adiante um programa específico voltado à fotografia. No entanto, a dificuldade de contratação do trabalho de terceiros pelo MAC-USP não teria favorecido a continuidade dessas colaborações. Claudia Andujar e George Love, por exemplo, tinham vínculos com o MASP onde atuavam como professores de fotografia e coordenadores de cursos. Andujar seria a primeira coordenadora do Departamento de Fotografia daquele Museu, criado em 1976. Boris Kossoy, por sua vez, também atuou na mesma época junto ao Museu de Arte de São Paulo, onde apresentou sua produção fotográfica em uma mostra individual em 1973, e organizou uma exposição sobre a história da fotografia brasileira no mesmo ano. Em 1977, Kossoy assumiria a direção do Departamento de Fotografia, no lugar de Claudia Andujar, que se afastou para dedicar-se à causa dos índios Yanomami. Além disso, Boris Kossoy iria intensificar seu trabalho como professor, crítico e pesquisador da área de fotografia naqueles anos ${ }^{150}$. Por outro lado, os demais membros da Comissão de Fotografia, designada por Zanini, oriundos de outros segmentos da área de fotografia, como o fotoclubismo e as escolas de fotografia, não chegaram a atuar efetivamente no MAC, por motivos que não pudemos esclarecer $^{151}$.

Considero lícito supor que não foram apenas as condições materiais que impediram a permanência dos membros da Comissão de Fotografia no MAC-USP, mas a própria orientação do Museu, que priorizava o entendimento da fotografia no contexto da arte contemporânea. A diluição da especificidade do medium não era particularmente interessante para profissionais que buscavam a institucionalização da fotografia e a sedimentação de campos específicos de trabalho e de estudo. Nesse sentido, pode-se dizer que a orientação de Pietro Maria Bardi em relação à fotografia no MASP era bem mais condizente com tais expectativas $^{152}$. Bardi tinha um interesse antigo pela fotografia, que já o acompanhava antes mesmo de sua vinda para o Brasil. Isso motivou-o, desde os primeiros anos do Museu de Arte de São Paulo, a implantar uma agenda regular não só de exposições, mas também de cursos, palestras, lançamentos de livros e outros eventos ligados à fotografia ${ }^{153}$.
149. Roberto Pontual. A Nova Fotografia. Jornal do Brasil, Rio de Janeiro, 1 nov. 1976. Arquivo MAC-USP. Sobre a arte conceitual no MAC-USP, ver Cristina Freire (1999).

50. No final da década de 1970 , Boris Kossoy atuou como professor do Curso de Especialização em Museologia, vinculado à Escola de Sociologia e Política de São Paulo, no qual ministrava disciplina sobre história da fotografia. Em 1977, organizou a mostra Tendências, no MASP. Em 1978, defendeu dissertação de Mestrado sobre Militão de Azevedo, na Escola de Sociologia e Política e, em seguida, a tese de doutorado que resultou no livro Origens e expansão da fotografia no Brasil. Em 1980, assumiu a direção do Museu da Imagem e do Som, onde permaneceu por três anos.

151. Faz-se necessário um mapeamento dos agentes que atuaram nesse período nos museus e outras instituições ligadas à fotografia, tendo em conta suas origens, formações e interesses, para um melhor entendimento das relações de poder que se estabeleceram na área naquele momento. A princípio salta aos olhos a presença marcante de fotógrafos estrangeiros imigrantes atuando nas instituições culturais e na imprensa entre nós, como Claudia Andujar, George Love e Maureen Bisilliat, para citar apenas os que foram tratados neste ensaio. Nota-se também o trânsito internacional desses agentes, como Claudia Andujar, que realizara, em 1958, mostra de seu trabalho na George Eastman House, de Rochester, e, em 1960, teve fotografias compradas para o acervo do MoMA por Edward Steichen. Ver Claudia Andujar (2005). O paulista Boris Kossoy, por sua vez, já contava em seu currículo com fotografias incorporadas ao acervo do 
MoMA no início da década de 1970 e, algum tempo depois, teve seu trabalho de pesquisa sobre a invenção da fotografia no Brasil por Hercules Florence reconhecido e certificado pela George Eastman House, de Rochester. Depoimento público de Boris Kossoy, fornecido à autora em aula do Curso de Especialização em Museus de Arte do Museu de Arte Contemporânea da USP no primeiro semestre de 2005.

152. Ao longo das décadas de 1950 e 1960, Bardi reuniu um grande conjunto de fotos, principalmente vistas e retratos, que não chegaram a integrar oficialmente o acervo do MASP. Ver: Ricardo Mendes 2004

153. Ver Pietro Maria Bardi (1987); e Carolina Coelho Soares (2006).

154. Entrevista concedida à autora em abril de 2006.

155. No final de 2005, a $6 \underline{a}$ Vara Federal Criminal transferiu para o MAC-USP parte da coleção do banqueiro Edemar Cid Ferreira, na qual se encontra um expressivo conjunto de cerca de 1000 fotografias. Essas fotos estão sob a guarda provisória do Museu e dependem de decisão judicial para serem ou não integradas definitivamente ao acervo. Em caso positivo, haverá uma grande transformação no perfil do acervo de fotografia do MAC. Ver: MUSEU de Arte Contemporânea amplia seu acervo iconográfico. In: USP. Calendário de Cultura e Extensão. São Paulo: USP-Pró-Reitoria de Cultura e Extensão, jun. 2006. Disponível também em <http:// www.usp.br/prc/calenda rio/sumario. php?link $=1 \&$ mes=junho $>$. Acesso em maio de 2008 .

156. As exceções, no que concerne especialmente às exposições, ficam por conta das fotografias de Hildegard Rosenthal e Alice Brill, que
Walter Zanini avalia que as exposições do MAC-USP realizadas na década de 1970 deram início a um "colecionismo multimídia" no Museu 154 . De fato, esse viés multimídia tornou-se prioritário em relação à incorporação de fotografias de caráter autoral, o que acabou por definir o perfil do conjunto de obras que entrou no acervo do MAC-USP naquela década. A gestão de Zanini determina ainda hoje o perfil do acervo de fotografia do MAC. Após os anos 1970, a Universidade não mais disponibilizaria verbas para aquisição de obras. Além disso, não foram estabelecidas políticas de incentivo a doações de fotografias para o MAC-USP, nem implementados projetos para ampliação do acervo. As incorporações de fotos realizadas nas décadas de 1980, 1990 e 2000 (pelo menos até 2004), não chegaram a transformá-lo significativamente ${ }^{155}$.

O trabalho de conservação e difusão de acervos institucionais não pode ser considerado como uma atividade meramente técnica. Conservar e difundir deve passar necessariamente pela operação de conferir sentido a um determinado patrimônio. Só assim, a conservação e a difusão podem ganhar relevância e justificativa sociais. A ausência de pesquisas sobre o conjunto de fotografias pertencente ao acervo do Museu de Arte Contemporânea da USP tem acarretado um silêncio sistemático sobre a sua existência, até nas próprias exposições e publicações do Museu produzidas nos últimos 30 anos $^{150}$. Somente um entendimento aprofundado sobre a constituição desse acervo e do debate no qual está inserida permitirá transformar essa situação. Quiçá este estudo seja o primeiro passo para tal resgate.

Considerações finais (ou quase)

O longo percurso que traçamos neste ensaio visou fornecer subsídios para refletirmos sobre o ingresso da fotografia nos museus de arte da cidade de São Paulo ${ }^{157}$. Se o Museu de Arte Moderna de Nova York constituiu-se em referência obrigatória nesse processo, isso não significa dizer que os museus brasileiros seguiram à risca suas lições. E nem poderiam. A fotografia foi assimilada pelo MoMA tendo como base a teoria modernista e, como suporte, uma complexa rede social de fotógrafos amadores e profissionais, ligados aos mercados da publicidade, da moda e do fotojornalismo; de alguns poucos, porém ativos, colecionadores e críticos; além da indústria e do comércio de equipamentos e materiais fotográficos ${ }^{158}$. No surgimento dos nossos museus modernos, no final da década de 1940, estávamos longe de possuir estrutura de apoio semelhante para a institucionalização da arte em geral, e menos ainda para a fotografia. Isso acarretou a ausência de uma reflexão teórica que referendasse 0 ingresso da fotografia nos museus locais e a falta de suporte financeiro necessário. O conceito de vintage print, por exemplo, não foi problematizado naquele momento nas instituições museológicas de São Paulo, muito embora tenha sido fundamental para a legitimação da fotografia artística 
nos museus modernos no exterior ${ }^{159}$. Alguns fotógrafos, especialmente os que tinham experiência fora do Brasil, preocupavam-se em assinar as cópias que vendiam ou doavam aos museus e/ou limitar a produção de novas tiragens. Não havia, no entanto, exigências institucionais em relação à adoção desses procedimentos, como se pode constatar na avaliação das cópias fotográficas incorporadas aos acervos dos museus estudados na década de 1970.

A assimilação da fotografia pelos museus nacionais ocorreu tardiamente em relação à experiência norte-americana e em circunstâncias históricas muito distintas. Logo de início o MAM-SP abriu espaço para exposições de fotógrafos ligados ao fotoclubismo, e passou a valorizar a foto documental e o fotojornalismo por ocasião da assimilação da fotografia em seu acervo. Esse itinerário reflete bem as mudanças de paradigma ocorridas, no campo da fotografia considerada artística, entre o final dos anos de 1940 e o fim da década de 1970. É quando ocorre uma profunda transformação da conjuntura política do país e observa-se a formação de um mercado para a fotografia, mesmo que incipiente. Nesse aspecto, é imprescindível apontar o fenômeno de surgimento de várias galerias comerciais que expunham e vendiam fotografias autorais nos anos $1970^{160}$.

Por outro lado, podemos estabelecer um paralelo entre o MAC e a Bienal de São Paulo quanto ao entendimento do papel da fotografia nos anos 1970. A posição de ambos dá conta da mudança ocorrida na passagem da arte moderna para a arte contemporânea e indica uma certa independência em relação aos valores que estavam sendo estabelecidos pelo incipiente mercado local de fotografia artística. Esta liberdade de ação, no caso do MAC, deveu-se, em grande medida, ao seu perfil universitário, o que inclui a formação acadêmica de seu diretor.

Uma releitura de Walter Benjamin pode ajudar-nos a refletir sobre o processo de incorporação da fotografia ao acervo do MAC-USP. O filósofo alemão propõe, já no início da década de 1930, que uma mudança de ponto de vista para se analisar a relação entre arte e fotografia pode, em certos casos, fazer uma grande diferença. "É característico que o debate tenha se concentrado na estética da 'fotografia como arte', ao passo que poucos se interessaram, por exemplo, pelo fato bem mais evidente da 'arte como fotografia'." 161

Se aceitarmos a sugestão de Benjamin, seremos capazes de reconhecer a riqueza do processo de incorporação da fotografia ao acervo do MAC-USP. O Museu possibilitou que seu público observasse a fotografia a partir de pontos de vista radicalmente distintos, ao fomentar exposições que afirmavam a fotografia como arte de caráter autoral e outras que partiam da premissa de que se podia fazer arte também por meio da fotografia. Podemos dizer que o Museu de Arte Contemporânea da USP assumiu plenamente, naquele momento, a sua vocação contemporânea, ao negar a autonomia da obra de arte, potencializar a dissolução de fronteiras entre os diferentes meios artísticos e oferecer a possibilidade de acesso a várias interpretações do fenômeno artístico.
- pelo caráter documental, pela temática ligada à cidade de São Paulo e pelo reconhecimento que obtiveram suas autoras - são mais facilmente assimiláveis e, por isso, têm sido expostas com certa regularidade no $\mathrm{Mu}$ seu.

157. Um panorama completo da situação institucional da fotografia em São Paulo na década de 1970 deve in cluir necessariamente a atuação do MASP e da Pinacoteca do Estado de São Paulo, o que não faz parte dos objetivos deste ensaio. Cabe destacar a experiência do Gabinete de Fotografia da Pinacoteca, idealizado por Fábio Magalhães, e que contou com o trabalho de curadoria de Rubens Fernandes Júnior

158. As bases dessa estrutura e seu funcionamento são muito bem descritos na tese de doutorado de Diana Dobranszky (2008).

159. Considera-se como vin tage print a cópia fotográfica produzida pelo próprio fotógrafo, ou por alguém por ele autorizado e/ou supervisionado, a partir do negativo original, durante um certo período de tempo após o ato fotográfico. Essa extensão de tempo é motivo de controvérsia entre diferentes autores e pode abranger algumas semanas, meses ou mesmo anos (em geral de um a cinco). Uma definição simplificada de vintage print pode ser encontrada em Gilles Mora (1998, p. 166).

160. Podemos citar: Enfoco (1971), Imagem-Ação (1976), Galeria Bonfiglioli (ca. 1973); Fotóptica (1979); Álbum (1980); Salão Fuji (1980). Cf.

161. Walter Benjamin (1994 p. 104) 
162. Jeff Wall (1998, p. 222 223). A discussão proposta por Jeff Wall é bem mais ampla e envolve muitos outros aspectos, como a relação entre a arte conceitual e o fotojornalismo, que não cabe aqui aprofundar. início de um dos textos de Lucy Soutter remete-nos à desconcertante experiência, vivida por diversos pesquisadores, dentre os quais me incluo, de colher depoimentos de artistas conceituais que negam ter se interessado pela fotografia - mesmo os que a utilizaram com intensidade. Apesar das evidências, esses artistas afirmam ter empregado a fotografia apenas de modo restrito e instrumental. Durante muitos anos, observa Soutter, curadores, críticos e historiadores corroboraram essa visão reducionista do papel da fotografia na arte conceitual. Hoje, com a proliferação de pesquisas sobre o conceitualismo nas mais diversas latitudes, podemos constatar o quão presente a fotografia esteve nos trabalhos dos artistas dos anos 1970 e somos levados a observar que não se tratava de um uso tão circunstancial quanto apregoavam os artistas, mas muito ao contrário. Nessa década, a imagem fotográfica passou a interessar aos artistas devido a muitas de suas propriedades: seja por sua presença capilar no tecido social; por sua filiação às convenções da representação e por sua suposta verossimilhança; seja por sua capacidade de registrar ações efêmeras e estabelecer uma ligação aparentemente direta com o mundo visível. Não podemos esquecer que a fotografia foi uma das ferramentas da aproximação entre arte e vida, opção tão cara aos artistas naqueles anos conturbados.

Cabe assinalar um fenômeno crucial neste processo. Se o discurso estético do modernismo logrou restringir as potencialidades da fotografia, a arte conceitual esgarçou ao extremo os seus limites, colaborando, mesmo que involuntariamente, para uma tomada de consciência ontológica do medium. A arte conceitual evidenciou a flexibilidade adaptativa da fotografia às mais distintas práticas artísticas e sua permeabilidade aos mais diferentes discursos. Jeff Wall chega mesmo a aventar a hipótese de que, somente após "a crítica mordaz e radical" aos pressupostos estéticos da fotografia artística levada à cabo pela arte conceitual, o sistema iria finalmente aceitar a fotografia como arte. Segundo ele, embora as condições estéticas para a assimilação da fotografia como arte já estivessem dadas desde a década de 1940, elas não foram acompanhadas de condições sociais compatíveis para tanto e, por isso, não resultaram na formação de um mercado para a fotografia antes dos anos 1970.

O fotoconceitualismo conduziu a uma aceitação total da fotografia como arte (arte autônoma, burguesa e colecionávell em virtude da insistência de que este medium podia gozar do privilégio de ser a própria negação do conceito de arte em todos os níveis. Ao constituir-se esta negação, romperam-se todas as barreiras. A fotografia, inscrita no novo vanguardismo e combinada com elementos de texto, escultura, pintura ou desenho, converteu-se na quintessência do "antiobjeto". Enquanto as neo-vanguardas re-estudaram e redescobriram as ortodoxias dos anos 20 e 30, os limites do campo da arte autônoma ampliaram-se inesperadamente ao invés de reduzir-se ${ }^{162}$.

A hipótese de Wall, por mais paradoxal que possa parecer à primeira vista, mereceria uma análise aprofundada de suas premissas e implicações. No entanto, é-nos suficiente, neste momento, considerar que ela fornece uma chave interpretativa eficiente, e particularmente instigante, para tentarmos compreender 
o fenômeno que resultou na forte presença da fotografia na arte dos dias que correm. Incluir a arte conceitual na história da fotografia, ou melhor, na história da cultura visual recente, da qual a fotografia é parte indissociável, talvez seja a única possibilidade de transpormos o abismo teórico que, na maioria dos estudos sobre o tema, ainda hoje persiste entre a fotografia da primeira e a da segunda metade do século XX. Ademais, incluir o museu nessas reflexões parece-me ser a chave para restituirmos a esse processo a complexidade que the é inerente.

Ainda sobre as relações entre arte e fotografia no museu

Se atualmente a relação entre arte e fotografia parece estar muito bem resolvida no mercado de arte - vide a presença maciça da fotografia nas exposições de arte contemporânea e os sucessivos recordes de preços por ela alcançados nos leilões internacionais -, o mesmo não podemos dizer em relação aos acervos dos museus de arte. A fotografia continua a desafiar os profissionais das áreas de documentação e curadoria dos museus de arte, em geral pouco preparados para lidar com as conseqüências da condição de múltiplo inerente à fotografia, e com o caráter híbrido que ela adquire ao imiscuir-se nas mais variadas práticas artísticas. Dois pesos, duas medidas: como compatibilizar, em um mesmo acervo, o tratamento dado à fotografia considerada artística, segundo a teoria modernista, e o tratamento conferido ao registro fotográfico, muitas vezes precário, de uma ação artística? Do ponto de vista tipológico, ambas são obras aparentemente idênticas, mas radicalmente distintas no que se refere ao processo de atribuição de valor artístico a que foram submetidas. Isso significa que ingressaram no acervo dos museus a partir de diferentes discursos de legitimação. O valor artístico, como sabemos, não se encontra materializado na cópia fotográfica em si e depende de atribuições fundamentadas em certas práticas sociais.

que dizer, então, dos objetos que em sua constituição agregam imagens fotográficas? A classificação de "técnica mista" - aplicada a obras, as mais díspares, presentes nas reservas técnicas dos museus - tem contribuído apenas para transformá-las em um conjunto de objetos inapreensíveis. Este é apenas um breve delineamento de alguns dos dilemas que o profissional de museu tem de enfrentar ao deparar-se com a presença multiforme da fotografia no campo da arte, sem entrarmos em considerações sobre a vasta problemática trazida mais recentemente pelas imagens eletrônicas.

Para finalizar, tomo a liberdade de fazer minhas as palavras de Douglas Crimp, quando ele afirma que "a fotografia sempre ultrapassará as instituições de arte, sempre participará de práticas não artísticas, será sempre uma ameaça à insularidade do discurso de arte"163. A advertência do autor serve para alertar-nos de que a relação entre arte e fotografia no museu talvez nunca venha de fato a ser domesticada. 


\section{REFERÊNCIAS}

X BIENAL sem fotografia. Íris, São Paulo, n. 209, 28 out. 1969.

A FOTOGRAFIA na 8ª Bienal. Boletim Foto Cine, São Paulo, n. 150, p. 18-19, dez. 1965.

AMARAL, Aracy. História de uma coleção. In: MUSEU DE ARTE CONTEMPORÂNEA DA UNIVERSIDADE DE SÃO PAULO. Perfil de um acervo. São Paulo: Techint, 1988. p.11-51.

AMARANTE, Leonor. As bienais de São Paulo, 1951-1987. São Paulo: Projeto, 1989.

ANDUJAR, Claudia. A vulnerabilidade do ser. São Paulo: Cosac Naify, 2005.

A NOTA do Mês. Boletim Foto Cine, São Paulo, n. 93, p. 9, out.-dez. 1954.

ARAÚJO, Marcelo Mattos. Os modernistas na Pinacoteca: o museu entre a vanguarda e a tradição. 2002. Tese (Doutorado em Arquitetura e Urbanismo) - Faculdade de Arquitetura e Urbanismo da Universidade de São Paulo, São Paulo, 2002.

Fernando Lemos: à sombra da luz, à luz da sombra. São Paulo: Pinacoteca do Estado de São Paulo, 2004.

ARAÚJO, Olívio Tavares de. Mãos na obra. Veja, São Paulo, p. 70-71, 2 jan. 1974.

BARBOSA, Ana Mae (Org.). As bienais no acervo do MAC, 1951-1985: catálogo. São Paulo, MACUSP, 1987.

(Ed.). O Museu de Arte Contemporânea da Universidade de São Paulo. São Paulo: Banco Safra, 1990.

BARDI, Pietro Maria. Em torno da fotografia no Brasil. São Paulo: Banco Sudameris, 1987.

BARROS, Geraldo. A sala de fotografia. Boletim Foto Cine, São Paulo, n. 87, p. 12-17, fev.-mar. 1954.

BARROS, Regina Teixeira de. Revisão de uma bistória: a criação do Museu de Arte Moderna de São Paulo, 1946-1949. 2002. Dissertação (Mestrado em Estética e História da Arte)-Escola de Comunicações e Artes da Universidade de São Paulo, São Paulo, 2002.

BENJAMIN, Walter. Pequena história da fotografia. In: Obras escolbidas, 1: magia e técnica, arte e política. São Paulo: Brasiliense, 1994. p. 91-107. [Deve ser este o citado com outra data].

. A obra de arte na era de sua reprodutibilidade técnica. In: Obras escolbidas, 1 : magia e técnica, arte e política. São Paulo: Brasiliense, 1994. p.165-196.

BIENAL DE SÃO PAULO, 8., 1965, São Paulo. Catálogo Geral.

BIENAL DE SÃO PAULO, 9., 1967, São Paulo. Catálogo Geral. 
BIENAL DE SÃO PAUlO, 10., 1969, São Paulo. Catálogo Geral.

BOLETIM FOTO CINE. São Paulo: FCCB, n. 148-149, set.-nov. 1965.

CAMARGO, Mônica Junqueira; MENDES, Ricardo. Fotografia: cultura e fotografia paulistana no século XX. São Paulo: Secretaria Municipal de Cultura, 1992.

CAMPANY, David. Art and photography. New York: Phaidon, 2003.

CAUQUELIN, Anne. L'art contemporain. Paris: Presses Universitaires de France, 1992.

CHEVRIER, Jean-François. The adventures of the picture form in the history of photography. In: FOGLE, Douglas. The last picture show: artists using photography, 1960-1982. Minneapolis: Walker Art Center, 2003. p. 113-128.

CHIARElli, Tadeu. (Ed.). O Museu de Arte Moderna de São Paulo. São Paulo: Banco Safra, 1998.

. A fotografia brasileira no acervo do Museu de Arte Moderna de São Paulo. In: MESQUITA, Ivo et alii (Org.). Fotografias no acervo do Museu de Arte Moderna de São Paulo. São Paulo: MAM-SP, 2002. p. 8-17.

COSTA, Helouise. Entrando por uma porta lateral. In: FotoGrafia: a experiência alemã dos anos 50: catálogo. São Paulo: AS Studio, 1995.

Waldemar Cordeiro: a ruptura como metáfora. São Paulo: Cosac Naify, 2001.

A fotografia no Brasil nas décadas de 1940 e 1950: a reinvenção das vanguardas. In: GONÇALVES, Lisbeth Rebollo. Arte Brasileira no Século XX. São Paulo: ABCA; MAC-USP; Imprensa Oficial do Estado, 2007. p. 191-204.

; SILVA, Renato Rodrigues da. A fotografia moderna no Brasil. São Paulo: Cosac Naify, 2004.

CRIMP, Douglas. On the museum's ruins. Cambridge, MA: The MIT Press, 1993.

DOBRANSZKY, Diana. A legitimação da fotografia no museu de arte: o Museum of Modern Art de Nova York e os anos Newhall no Departamento de Fotografia. 2008. 2 v. Tese (Doutorado em Multimeios)-Instituto de Artes da Universidade Estadual de Campinas, Campinas, SP, 2008.

DUBOIS, Philippe. A arte é (tornou-se fotográfica)? Pequeno percurso das relações entre a arte contemporânea e a fotografia no século XX. In: DUBOIS, Philippe. O ato fotográfico. Campinas, SP: Papirus, 1994. p. 251-299.

DRYANSKY, Larisa. Le musée George-Eastman: une autre histoire de la photographie américaine? Études photographiques, Paris, n. 21, p. 74-93, déc. 2007.

ENWEZOR, Okwui. Archive fever: photography between history and the monument. In: Archive fever: uses of the documents in contemporary art. New York; Göttinger: Internacional Center of Photography; Steidl, 2008. p. 12-51.

Annals of Museu Paulista. v. 16. n.2. July - Dec. 2008. 
EXPOSIÇÃO INTERNACIONAL de Arte Fotográfica na IX Bienal de São Paulo. Íris, São Paulo, n. 180, 10 maio 1967.

FABRIS, Annateresa. Entre o estético e o artístico: o uso da imagem fotográfica nas tendências desmaterializadas. In: SECRETARIA DE ESTADO DA CULTURA. Seminários Panorama da imagem: caderno de textos. São Paulo: Secretaria de Estado da Cultura, 1996. p. 3-9.

A pós-imagem mecanizada: fotografia e arte pop. Revista do Patrimônio Histórico e Artístico Nacional, Rio de Janeiro, n. 27, p. 290-229, dez. 1998.

FREIRE, Cristina. Poéticas do processo: arte conceitual no museu. São Paulo: Iluminuras, 1999.

FRIZOT, Michel; VEIGY, Cédric Photo trouvée. London: Phaidon, 2006.

FOGLE, Douglas. The last picture show: artists using photography, 1960-1982. Minneapolis: Walker Art Center, 2003.

FUNDAÇÃO BIENAL DE SÃO PAULO. Bienal 50 anos, 1951-2001. São Paulo: Fundação Bienal de São Paulo, 2001.

GODFREY, Tony. Looking at others: artists using photography. In: Conceptual Art. London: Phaidon, 1998. p. 299-342.

GONÇALVES, Paula Chrystina Scarpin. Vale das Rosas. Hildegard Rosenthal, pioneira do fotojornalismo no Brasil. 2007. Trabalho de Conclusão de Curso (Graduação)- Departamento de Jornalismo e Editoração, Escola de Comunicações e Artes da Universidade de São Paulo, São Paulo, 2007.

HERZOGENRATH, Wulf. Distanz und Nabe [Distância e proximidade]: catálogo [encarte em português]. São Paulo: Instituto Goethe, 2003. Acessível em: <www.culturgest.pt/docs/encarte. pdf>. Acesso em novembro de 2008.

JURECKI, Krzysztof. The bistory of polish photography to 1990. Acessível em: <http://www. culture.pl/en/culture/artykuly/es_historia_fotografii>. Acesso em março de 2008.

KRAUSS, Rosalind. Les espaces discursifs de la photographie. In: Le photograpbique. Paris: Macula, 1990.

KRAUSS, Rosalind. Le photographique. Paris: Macula, 1990.

KOSSOY, Boris. Viagem pelo fantástico. São Paulo: Kosmos, 1971.

Fotografia. In: ZANINI, Walter (Org.). História geral da arte no Brasil, 2. São Paulo: Instituto Walter Moreira Salles, 1983. p. 867-913.

LOURENÇO, Maria Cecília França. Museus acolbem moderno. São Paulo: Edusp, 1999.

LUZ, Celina. Os espelhos da vida de Sérgio Augusto Porto. Jornal do Brasil, Rio de Janeiro, 17 out. 1973.

MAC-USP. Beleza de Pedra. São Paulo: catálogo de exposição, 1969.

Cartier-Bresson, fotografias recentes. São Paulo: catálogo de exposição, 1970. 
Hildegard Rosenthal. Fotografias. São Paulo: catálogo de exposição, 1974.

Fotografia experimental polonesa. São Paulo: catálogo de exposição, 1974.

Fotógrafos contemporâneos V. São Paulo: catálogo de exposição, 1973.

Fotógrafos de São Paulo: catálogo de exposição, 1971.

O fotógrafo desconbecido. São Paulo: catálogo de exposição, 1972.

70 fotos de Brassaï. São Paulo: catálogo de exposição, 1974.

MARTINS, Mariana. Presenças e ausências: a fotografia no Museu de Arte Moderna de São Paulo, 1948-1980. 2005. Monografia de conclusão (Curso de Especialização em Museus de Arte)-Museu de Arte Contemporânea da Universidade de São Paulo, São Paulo, 2005.

MENDES, Ricardo. Reflexos do Brasil: uma leitura inicial da Coleção Pirelli/Masp de Fotografia. JORNADA DE ESTUDOS REPRESENTAÇÕES DO BRASIL: DA VIAGEM MODERNA ÀS COLEÇÕES FOTOGRÁfICAS. Comunicação. São Paulo: Museu Paulista da Universidade de São Paulo, dez. 2004.

. Para que servem as coleções (fotográficas)? In: MESQUITA, Ivo et alii (Org.). Fotografias no acervo do Museu de Arte Moderna de São Paulo. São Paulo: MAM-SP, 2002. p. 18-21.

Once upon a time: a história da história da fotografia brasileira. Anais do Museu Paulista, São Paulo, nova série, n. 6-7, p. 183-205, 1998-1999 (lançado em 2004).

MORA, Gilles. Pboto Speak. A guide to the ideas, movements and techinques of photography, from 1839 to the present. New York: Abbeville, 1998.

NEWHALL, Beaumont. Focus. Memoirs of a life in photography. Boston: Bulfinch, 1993.

OITICICA FILHO, José. Os brasileiros no IX Salão Internacional de São Paulo. Boletim Foto Cine, São Paulo, n. 54, out. 1950

OLIVEIRA, Rita Alves de. A Bienal de São Paulo: forma histórica e produção cultural. 2001. Tese (Doutorado em Ciências Sociais)-Programa de Ciências Sociais da Pontifícia Universidade Católica de São Paulo, São Paulo. 2001.

PEDROSA, Mario. A Bienal de cá para lá. In: ARANTES, Otília (Org.). Política das Artes: Mário Pedrosa. São Paulo: Edusp, 1995. p. 217-284.

PFEIFFER, Wolfgang. Ademar Manarini: fotógrafo. In: CAMP, Freddy Van (Org.). Ademar Manarini: fotografia. Rio de Janeiro: Expressão e Cultura, 1992.

Relações históricas entre o MAM, a Bienal e o MAC. In: BARBOSA, Ana Mae (Org.). As bienais no acervo do MAC, 1951-1985: catálogo. São Paulo: MAC-USP, 1987, p. 15-18.

PHILLIPS, Christopher. The judgment seat of photography. October, v. 22, p. 27-63, Autumn, 1982.

PONTUAL, Roberto. Villalba: a mística da dor. Jornal do Brasil, Rio de Janeiro, 8 ago. 1974. 
Entre dois séculos. Rio de Janeiro: Editora JB, 1987.

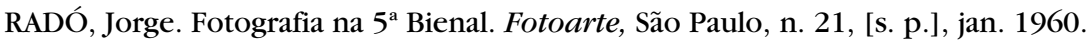

ROBERTS, John (Ed.). The impossible document: photography and conceptual art in Britain, 1966-1976. London: Camerawork, 1997.

SHARF, Aaron. Art and photography. London: Penguin, 1979.

SOARES, Carolina Coelho. Coleção Pirelli-Masp de fotografia: fragmentos de uma memória. 2006. Dissertação (Mestrado em Artes)-Escola de Comunicações e Artes da Universidade de São Paulo, São Paulo, 2006.

SOBOTA, Adam. Polish photography. Acessível em <http://www.culture.pl/en/culture/artykuly/ es_fotografia_polska>. Acesso em março de 2008.

SOLOMON-GODEAU, Abigail. Essays on photography, bistory, institutions and practices. Minneapolis: University of Minnesota Press, 1991.

SOUTTER, Lucy. The photographic idea: reconsidering conceptual photography. Afterimage, Rochester, NY, v. 26, n. 5, Mar.-Apr. 1999.

SZARKOWSKI, John. Looking at photographs: 100 Pictures from the Collection of the Museum of Modern Art. New York: MoMA, 1973.

Modos de olbar [Looking at photography]: catálogo. São Paulo; New York: MAM; MoMA, 1999.

The photographer's eye (1966). New York: MoMA, 2007.

UNIVERSIDADE NOVA DE LISBOA. Dicionário eletrônico de termos literários. Acessível em: $<$ http://www.fcsh.unl.pt/>

VIALE, Marie-Laure. Quelle(s) définition(s) du tableau photographique? 1994. 138 f. Dissertação (Mestrado em História da Arte)-Université Rennes II, Rennes, 1994.

WALL, Jeff. Señales de indiferencia: aspectos de la fotografía en el arte conceptual o como arte conceptual. In: PICAZO, Glòria \& RIBALTA, Jorge (Ed.). Indiferencia y Singularidad: la fotografía en el pensamiento artístico contemporáneo. Barcelona: Gustavo Gili, 2003.

ZANINI, Walter. Fotografia, arte? Boletim Foto Cine, São Paulo, n. 92, p. 13-14, set. 1954.

(org). História geral da arte no Brasil. São Paulo: Instituto Walther Moreira Salles, 1983. $2 \mathrm{v}$.

. Arte e história da arte. Estudos Avançados, São Paulo, v. 8, n. 22, p. 487-489, 1994. 
SITES

$<$ http://bienalsaopaulo.globo.com/>.

$<$ http://www.boriskossoy.com/>.

$<$ http://www.culture.pl/en/>.

$<$ http://www.edruscha.com/site/chronology.cfm>.

$<\mathrm{http}: / /$ www.dariovillalba.com/>.

Artigo apresentado em 5/2008. Aprovado em 10/2008. 